Boise State University

ScholarWorks

\title{
A Combined Field and Numerical Approach to Understanding Dilute Pyroclastic Density Current Dynamics and Hazard Potential: Auckland Volcanic Field, New Zealand
}

\author{
Brittany D. Brand \\ Boise State University \\ Darren Gravley \\ University of Canterbury \\ Amanda Clarke \\ Arizona State University \\ Jan Lindsay \\ University of Auckland \\ Simon H. Boomberg \\ University of Canterbury
}

See next page for additional authors

\section{Publication Information}

Brand, Brittany D.; Gravley, Darren; Clarke, Amanda; Lindsay, Jan; Boomberg, Simon H.; Agustin-Flores, Javier; and Németh, Károly. (2014). "A Combined Field and Numerical Approach to Understanding Dilute Pyroclastic Density Current Dynamics and Hazard Potential: Auckland Volcanic Field, New Zealand". Journal of Volcanology and Geothermal Research, 276, 215-232. https://doi.org/10.1016/ j.jvolgeores.2014.01.008

NOTICE: this is the author's version of a work that was accepted for publication in Journal of Volcanology and Geothermal Research. Changes resulting from the publishing process, such as peer review, editing, corrections, structural formatting, and other quality control mechanisms may not be reflected in this document. Changes may have been made to this work since it was submitted for publication. A definitive version was subsequently published in Journal of Volcanology and Geothermal Research, (2014). DOI: 10.1016/j.jvolgeores.2014.01.008 


\section{Authors}

Brittany D. Brand, Darren Gravley, Amanda Clarke, Jan Lindsay, Simon H. Boomberg, Javier Agustin-Flores, and Károly Németh

This article is available at ScholarWorks: https://scholarworks.boisestate.edu/geo_facpubs/186 


\section{Accepted Manuscript}

A combined field and numerical approach to understanding dilute pyroclastic density current dynamics and hazard potential: Auckland Volcanic Field, New Zealand

Brittany D. Brand, Darren Gravley, Amanda Clarke, Jan Lindsay, Simon H. Boomberg, Javier Agustin-Flores, Károly Németh

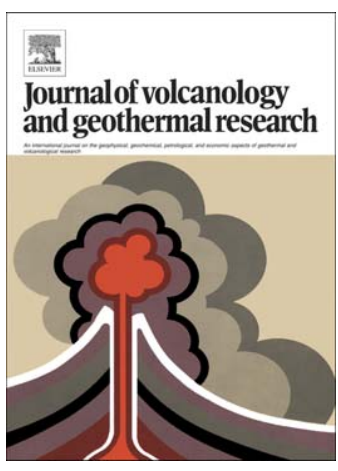

PII:

S0377-0273(14)00028-6

DOI:

doi: 10.1016/j.jvolgeores.2014.01.008

Reference:

VOLGEO 5257

To appear in:

Journal of Volcanology and Geothermal Research

Received date:

11 June 2013

Accepted date: $\quad 31$ January 2014

Please cite this article as: Brand, Brittany D., Gravley, Darren, Clarke, Amanda, Lindsay, Jan, Boomberg, Simon H., Agustin-Flores, Javier, Németh, Károly, A combined field and numerical approach to understanding dilute pyroclastic density current dynamics and hazard potential: Auckland Volcanic Field, New Zealand, Journal of Volcanology and Geothermal Research (2014), doi: 10.1016/j.jvolgeores.2014.01.008

This is a PDF file of an unedited manuscript that has been accepted for publication. As a service to our customers we are providing this early version of the manuscript. The manuscript will undergo copyediting, typesetting, and review of the resulting proof before it is published in its final form. Please note that during the production process errors may be discovered which could affect the content, and all legal disclaimers that apply to the journal pertain. 
NOTICE: this is the author's version of a work that was accepted for publication in Journal of Volcanology and Geothermal Research. Changes resulting from the publishing process, such as peer review, editing, corrections, structural formatting, and other quality control mechanisms may not be reflected in this document. Changes may have been made to this work since it was submitted for publication. A definitive version was subsequently published in Journal of Volcanology and Geothermal Research, (2014). DOI: 10.1016/j.jvolgeores.2014.01.008

Manuscript Title: A combined field and numerical approach to understanding dilute pyroclastic density current dynamics and hazard potential: Auckland Volcanic Field, New Zealand

Corresponding Author: Brand, Brittany D. ${ }^{1}$

Corresponding Author Email: brittanybrand@ boisestate.edu

List of Authors: Brittany D Brand ${ }^{1,}$ Darren Gravley ${ }^{2}$, Amanda Clarke ${ }^{3}$, Jan Lindsay ${ }^{4}$, Simon H Boomberg $^{2}$, Javier Agustin-Flores ${ }^{5}$, Károly Németh ${ }^{5}$

Author Affiliations: ${ }^{1}$ Department of Geosciences, Boise State University, Boise, Idaho 83725-1535; ${ }^{2}$ Geologic Sciences, University of Canterbury, Christchurch, New Zealand; ${ }^{3}$ School of Earth and Space Exploration, Arizona State University, Tempe, Arizona; ${ }^{4}$ School of Environment, The University of Auckland, New Zealand; ${ }^{5}$ Volcanic Risk Solutions, Massey University, Palmerston North, New Zealand. 


\section{Introduction}

Phreatomagmatic eruptions occur when rising magma explosively interacts with subsurface or surface water (Morrissey et al., 2000). The most dangerous and deadly phenomenon associated with this style of eruption are dilute pyroclastic density currents (PDCs), often called 'base surges' when formed during phreatomagmatic volcanism (e.g., Wohletz and Sheridan, 1979). Base surges are turbulent, ground-hugging clouds of gas and ash that travel radially away from an explosive center (Wohletz and Sheridan, 1979; Wohletz, 1998; Mastin and Witter, 2000). The combination of high velocities and the presence of solids can result in dynamic pressures in excess of $100 \mathrm{kPa}$, which have grave effects on the infrastructure they encounter (Valentine, 1998). The eruptive products of phreatomagmatic eruptions are commonly dominated by base surge deposits - each eruption producing tens to thousands of base surges depending on the duration and availability of external water (e.g., Moore, 1967; Waters and Fisher, 1971; Crowe and Fisher, 1973; Schmincke et al., 1973; Sohn and Chough, 1989; Cole et al., 2001; Brand and Heiken, 2009). Thus understanding their hazard potential is of great importance to predicting the consequences and risks of such eruptions.

The Auckland Volcanic Field (AVF) provides an ideal location to study the transport dynamics and assess potential hazards associated with base surges. Volcanic products, which range in age from 250 to $0.6 \mathrm{ka}$ (Shane and Sandiford, 2003; Brothers and Golson, 1959; Lindsay et al., 2010), cover an area of $360 \mathrm{~km}^{2}$ and consist of $\sim 50$ eruptive centers, 39 of which produced explosive phreatomagmatic eruptions (Searle, 1964; Kermode, 1992). Allan and Smith (1994) estimated that $\sim 71 \%$ of past AVF eruptions have had a base surge-producing phreatomagmatic phase. 
The AVF is populated by $>1.3$ million residents in the city of Auckland (Statistics New Zealand, 2006), providing additional incentive to understand the hazards and risk associated with a future AVF eruption. The relatively high sea level and abundant aquifers in the Miocene sediments beneath the AVF indicate a high probability that the initial phase of future AVF eruptions will be phreatomagmatic in nature (Lindsay et al., 2010; Sandri et al., 2012). The probability of a future phreatomagmatic eruption, combined with the uncertainty of vent location and size of a future eruption(s), has motivated focused research on past and possible future phreatomagmatic eruptions and base surges in the AVF (e.g., Searle, 1964; Kermode, 1992; Smith and Allen, 1993; Allen and Smith, 1994; Magill and Blong, 2005; Lindsay et al., 2010; Sandri et al., 2012; Bebbington and Cronin, 2011).

The primary objective of this work is to gain a better understanding of flow dynamics and hazard potential of base surges by combining field observations and numerical methods, and to explore the implications of this analysis on future eruptions in the AVF and elsewhere. We incorporate field observations from the Maungataketake tuff ring, which provides one of the best exposures of dilute PDC deposits in the AVF, with a quantitative model for flow of and sedimentation from a radially-spreading, steady-state, depth-averaged dilute PDC to explore the primary controls on transport dynamics, depositional mechanisms and dynamic pressures. The paper begins by describing the eruptive sequence of the Maungataketake tuff ring, focusing primarily on the lowermost portion of the sequence which incorporates podocarp trees snapped by base surges early in the eruption (e.g., Hayward and Hayward, 1996). Next we use depositional characteristics of the basal surge deposits and tree blow down patterns to reconstruct dynamic pressure and emplacement conditions of the early base surges generated during the eruption. Third we present the numerical approach and constrain conditions within the early base 
surges by reproducing the estimates of dynamic pressure and current runout distance. Finally we systematically vary initial conditions one variable at a time to (1) explore the first-order controls on base surge dynamics, and (2) assess the hazards associated with base surges generated from phreatomagmatic eruptions of this size and larger and the potential impact of a future eruption in the AVF.

\section{Geologic Setting - Maungataketake tuff ring}

Maungataketake is a small tuff ring-scoria cone complex, located adjacent to the Manukau Harbour in southern Auckland City (Figure 1 and 2). The scoria cone was originally close to 80 meters high before human occupation of the area. The earliest Maori settlers reshaped the scoria cone as a large fortified and terraced structure (Figure 2). Quarrying operations began in the early $20^{\text {th }}$ century, removing the majority of the scoria cone visible in Figure 2. The outer tuff ring structure is so subtle that it is difficult to discern in aerial photographs (cf. Figure 2); however, the structure can be detected by high resolution LiDAR (Light Detection And Ranging; courtesy of the Auckland Council) data. Figure 3 is a Digital Elevation Model (DEM) constructed from LiDAR data that clearly shows, outboard from where the scoria cone used to be, the complex rim of the tuff ring. The tuff ring appears to be a nested complex, suggesting multiple vents, a migrating vent, or multiple episodes of varying scale during the phreatomagmatic phases of the eruption.

Maungataketake is one of the few volcanoes in the urbanized area of Auckland City with an exposed cross section through a tuff ring, revealing an eruptive sequence dominated by base surge deposits. The Maungataketake eruption deposits are between 180 and $200 \mathrm{ka}$, based on a combination of paleo-environment and climate reconstruction and optically stimulated luminescence dating (Marra et al., 2006). More recent dating yields ages of $83-92 \mathrm{ka}+/-2 \mathrm{ka}$ 
(G. Leonard pers. comm. 2013). The sea level in OIS5 was about the same as in OIS7, thus the

Marra et al. (2006) reconstruction is also consistent with this younger age.

\section{Maungataketake Pyroclastic Deposits and Stratigraphy}

The pyroclastic deposits at Maungataketake are best exposed northwest and southeast of the crater (refer to Figure 3 for outcrop locations S1 to S6). Exposures on the northwest of the tuff ring are less than a meter thick and found only locally (S1 and S2). The thickest section of pyroclastic deposits is $\sim 15$ meters (largely inaccessible) and found $\sim 100 \mathrm{~m}$ west-northwest of S3. Deposits thin toward the southeast to $\sim 7 \mathrm{~m}$ at S3, $4 \mathrm{~m}$ at $\mathrm{S} 5$, and down to $0.75 \mathrm{~m}$ at $\mathrm{S} 6$. Deposits are only a few centimeters thick at the distal exposures, which are $\sim 0.6 \mathrm{~km}$ to the southeast of S6 (not shown on Figure 3 map).

The contact between the pyroclastic deposits and an organic-rich pre-volcanic substrate is exposed along the south side of the tuff ring along the beach section, but is obscured due to vegetation and mass wasting north of section S3. The pre-eruptive substrate consists of gently undulating, black, carbonaceous muds containing a fossil forest of large, $>2.5 \mathrm{~m}$ diameter, $25 \mathrm{~m}$ long kauri trees (Hayward and Hayward, 1996; Marra et al., 2006). The trees of the fossil forest occur as stumps in growth position and as downed tree trunks with no preferred orientation. The large stumps and downed trees are interpreted to have fallen prior to the eruption and, at the time of eruption, were decomposing in a wetland environment (Hayward and Hayward, 1996; Marra et al., 2006). A forest dominated by Podocarpus totara trees (conifers) with diameters of $<1 \mathrm{~m}$ was growing out of the wetland prior to the Maungataketake eruption (Hayward and Hayward, 1996; Marra et al., 2006). Trunks, limbs and branches of these trees are found lying down and incorporated within the first $1.5 \mathrm{~m}$ of pyroclastic deposits or encapsulated in growth position. 
NOTICE: this is the author's version of a work that was accepted for publication in Journal of Volcanology and Geothermal Research. Changes resulting from the publishing process, such as peer review, editing, corrections, structural formatting, and other quality control mechanisms may not be reflected in this document. Changes may have been made to this work since it was submitted for publication. A definitive version was subsequently published in Journal of Volcanology and Geothermal Research, (2014). DOI: 10.1016/j.jvolgeores.2014.01.008

The pyroclastic deposits contain both juvenile ash and scoria, and accidental clasts composed of sedimentary rocks from mudstone to a pebbly sandstone-conglomerate. The accidental components were likely incorporated from the unconsolidated Pliocene coastal sediments overlying the Waitemata Group sedimentary rock basement, which are 50-60 meters in this region and the source of abundant groundwater (Edbrooke et al., 2003). Larger lithic fragments, commonly found as ballistics with associated bedding plane sags are from the deeper Waitemata Group.

Figure 4 depicts a generalized stratigraphic section for the pyroclastic sequence. We describe the stratigraphy with the goal of identifying dominant transportation and depositional mechanisms of pyroclasts for different phases of the eruption, but focus mainly on the basal depositional conditions responsible for the downed trees of the podocarp forest growing from the wetland. A more detailed stratigraphy and investigation into eruption dynamics, magma fragmentation style and the overall evolution of the small-volume volcano of Maungataketake will be addressed in a complimentary paper by Agustin-Flores et al. (submitted).

The stratigraphy is divided into a non-volcanic package (NV), three phreatomagmatic packages (PH1, PH2 and PH3), and one magmatic package (M1). These packages are composed of several different lithofacies (see Table 1 and Appendix 1). PH1 is composed of gray, planar-, wavy- and cross-stratified tuff and lapilli tuff (Figure 4a, 4c-d). The first half of PH1 (0.5 to 1.5 meters depending on the outcrop location) is dominated by $10-20 \mathrm{~cm}$ thick, massive to faintly laminated, fine- to medium-grained ash beds (T1) with $\sim 7 \mathrm{~cm}$ thick interbeds of ungraded fine to medium ash (T2). Alternating sequences of T1 and T2 continue up section with interbeds of 1$10 \mathrm{~cm}$ thick, ungraded to reverse-graded, clast supported coarse ash (T3) and fine lapilli strata (LT2). Individual beds are on the order of millimeters to centimeters and are typically wavy. 
NOTICE: this is the author's version of a work that was accepted for publication in Journal of Volcanology and Geothermal Research. Changes resulting from the publishing process, such as peer review, editing, corrections, structural formatting, and other quality control mechanisms may not be reflected in this document. Changes may have been made to this work since it was submitted for publication. A definitive version was subsequently published in Journal of Volcanology and Geothermal Research, (2014). DOI: 10.1016/j.jvolgeores.2014.01.008

Rip up clasts of the black, organic rich substrate and tree trunks, limbs and fragments are common within the first 1.5 meters (Figure 4c). Soft sediment deformation is pervasive as ballistic-derived bedding plane sags and as loading flame structures. Accretionary lapilli are found in distal locations in the finer-grained beds.

$\mathrm{PH} 2$ differs from $\mathrm{PH} 1$ in that it contains a higher proportion and more consistent alternation of planar, reverse-graded, fine to medium lapilli beds (Figure 4a, e). PH2 is up to $3 \mathrm{~m}$ thick and thins to $<1 \mathrm{~m}$ south of the tuff ring rim and eventually pinches out due to erosion of the upper stratigraphy. PH2 alternates from 0.25 to $0.75 \mathrm{~m}$ thick packages of fine-grained, dominantly matrix supported, $\sim 7 \mathrm{~cm}$ thick beds of ungraded to reverse-graded, laminated to cross-laminated fine to medium ash (T2 and $\mathrm{T} 3$ ) with $1-2 \mathrm{~mm}$ thick, laterally discontinuous strings of coarse juvenile ash (lower part of picture in Figure 4e). These strata grade into similarly thick packages of commonly reverse-graded, grain-supported, coarse ash and fine lapilli strata (T5 and LT3; upper part of picture in Figure 4e). Interbeds of T2 and T3 are common in the grain-supported strata (Figure 4e). Strata commonly pinch and swell laterally. The coarser-grained T5 and LT3 beds are planar-bedded and laterally continuous. Soft sediment deformation is pervasive in $\mathrm{PH} 2$ as ballistic-derived bedding plane sags and as loading flame structures. Accretionary lapilli are found in the finer-grained beds of $\mathrm{T} 2$ and $\mathrm{T} 4$.

PH3 is a light-toned, fine-grained, planar-, wavy- and cross-laminated to stratified tuff with minor lapilli tuff (Figure 4a, 4f-g). The deposits are dominated by centimeter-thick beds that alternate from planar with faint laminations and cross laminations to cross-stratified (T4, T6 and T7). PH3 has far less coarse ash and lapilli than PH1 or PH2, and instead is dominated by alternating ash beds with minor coarse ash and fine lapilli strata. The coarser beds are more common towards the base of $\mathrm{PH} 3$, but the deposits become increasingly finer-grained vertically 
NOTICE: this is the author's version of a work that was accepted for publication in Journal of Volcanology and Geothermal Research. Changes resulting from the publishing process, such as peer review, editing, corrections, structural formatting, and other quality control mechanisms may not be reflected in this document. Changes may have been made to this work since it was submitted for publication. A definitive version was subsequently published in Journal of Volcanology and Geothermal Research, (2014). DOI: 10.1016/j.jvolgeores.2014.01.008

upward through the stratigraphic sequence. Outsized juvenile fine-to-medium lapilli make up $<3 \%$ of the deposits. Soft sediment deformation is pervasive in PH3, mostly in the form of ballistic-derived bedding-plane sags. In most locations PH3 deposits are heavily altered to clay and have a pronounced, brownish-red oxidation horizon that extends down through the overlying M1 package and into PH3 from soil above (Figure 4f). As such, the original grain size and textures are difficult to discern where PH3 is in contact with the overlying soil.

M1 unconformably overlies the top of PH3 (Figure 4g). It consists of well-sorted, centimeter-thick, plane-parallel and diffusely laminated red scoria ash and lapilli beds. Subtle grain size variations are noted as the M1 package is characterized by alternating T8 and LT4 lithofacies. Both normal and reverse grading is common. M1 is found only $\sim 185 \mathrm{~m}$ westnorthwest of S3 (likely eroded elsewhere, as discussed below) and represents the last pyroclastic package in the stratigraphy. Where found, M1 is up to 2.3 meters thick and strongly oxidized, although the total thickness is obscured due to a variable weathering horizon that extends down into M1 from the soils above. The grains are $99 \%$ juvenile with $<1 \%$ accidental component. There is no soft sediment deformation or evidence for liquid water at the time of deposition.

\section{Maungataketake Stratigraphic Interpretation}

Accidental clasts within the Maungataketake eruptive sequence suggest the eruption occurred when basaltic magma encountered and explosively interacted with near-surface groundwater residing in fractures within Miocene sedimentary rocks (Waitemata Group, deep water turbidite succession), the matrix of overlying Pliocene "soft" alluvial/coastal sediments, and/or shallow standing water in swamps or coastal lakes (Agustin-Flores et al., submitted). The three phreatomagmatic packages record deposition primarily from base surges with a minor component of fall out. The overall thinning of these packages from S3 to S6 suggests the general 

resulting from the publishing process, such as peer review, editing, corrections, structural formatting, and other quality control mechanisms may not be reflected in this document. Changes may have been made to this work since it was submitted for publication. A definitive version was subsequently published in Journal of Volcanology and Geothermal Research, (2014). DOI: 10.1016/j.jvolgeores.2014.01.008

transport direction was from north to south. PH1 is dominated by thin, matrix-supported strata and cross strata that pinch and swell laterally, suggestive of lateral transport in a dilute PDC, with a minor component of well-sorted, laterally continuous strata (T4) that could be related to a minor fall component co-emplaced with or deposited between pulses of surges (cf. Wohletz and Sheridan, 1979; Sohn and Chough, 1989; Branney and Kokelaar, 2002). PH2 contains a slightly higher percentage of semi-laterally continuous, clast supported beds (e.g., T5 and LT3), interpreted as fallout through or between density currents, but the undulating and cross-bedded nature of the deposits and common reverse grading suggests the primary depositional mechanism was base surges. PH3 is finer-grained and better sorted than the underlying packages, suggesting more efficient fragmentation at the vent (Wohletz and McQueen, 1984; Buettner and Zimanowski, 1998; Morrisey et al., 2000). Soft sediment deformation, vesiculated tuff and accretionary lapilli are pervasive in $\mathrm{PH} 1-\mathrm{PH} 3$, suggesting the deposits contained liquid water at the time of deposition, and the influence of external water was important throughout the phreatomagmatic phase (e.g., Fisher and Schmincke, 1984; Heiken and Wohletz, 1985; Brand and Clarke, 2009). There is no evidence of the magma losing contact with the external water source (eruption "drying out") during this phreatomagmatic phase (e.g., Brand and White, 2007).

M1 unconformably overlies PH3, suggesting a time break between the phreatomagmatic and magmatic phases of the eruption. The lack of a soil horizon at this contact suggests the pause was geologically short, but is otherwise unconstrained. The scoriaceous nature of the clasts in M1 and lack of ash suggests a shift from phreatomagmatic to magmatic fragmentation (e.g., Houghton et al., 1996), representing a shift to magmatic lava-fountaining or Strombolian eruptions. The well-sorted, planar, laterally continuous nature of the scoria beds and the location 
NOTICE: this is the author's version of a work that was accepted for publication in Journal of Volcanology and Geothermal Research. Changes resulting from the publishing process, such as peer review, editing, corrections, structural formatting, and other quality control mechanisms may not be reflected in this document. Changes may have been made to this work since it was submitted for publication. A definitive version was subsequently published in Journal of Volcanology and Geothermal Research, (2014). DOI: 10.1016/j.jvolgeores.2014.01.008

of M1 (west-northwest of S3; Figure 3) correlates well with fallout from the nearby, now quarried, scoria cone.

\section{Variations in the Basal Base Surge Deposits (PH1)}

This work focuses on the earliest phase of the eruption (represented by PH1) because the deposit characteristics and distribution of the trees incorporated into or buried by the base surge deposits allow us to constrain the dynamic characteristics of the base surges. In this section we (1) explain in more detail the lateral lithofacies changes within PH1 and the distribution of the ballistics, tree fragments and tree casts, and (2) constrain the location of the early vent based on depositional characteristics within the lower sequence.

As noted above, the lower portion of the Maungataketake tuff ring pyroclastic deposits contain sub-horizontal trunks, limbs and fragments of Podocarp trees $\leq 0.5 \mathrm{~m}$ in diameter as far away from the rim of the tuff ring as location S4 (Figure 3). Within this region the trees were likely snapped near their base as there is no evidence for uprooting (no tree roots within the deposits) and no standing remnants to suggest that trees were snapped at a higher level. At locations farther from the tuff ring the trees were encapsulated and buried in growth position, although the larger, preserved trees found between S3 to S5 are broken at heights of $2 \mathrm{~m}$, as described in more detail below. We interpret the trees to have been snapped by the dynamic pressure of the early current(s) up to location S4, and the dynamic pressures to have decreased in the distal reaches to below the critical threshold for toppling the forest. The primary supporting evidence for this interpretation is the preferred orientation of the trees in the probable direction of flow.

An alternative explanation for the downed trees is that they fell under the weight of the accumulating ash. However, the ash deposits wouldn't have been more than a couple meters 
NOTICE: this is the author's version of a work that was accepted for publication in Journal of Volcanology and Geothermal Research. Changes resulting from the publishing process, such as peer review, editing, corrections, structural formatting, and other quality control mechanisms may not be reflected in this document. Changes may have been made to this work since it was submitted for publication. A definitive version was subsequently published in Journal of Volcanology and Geothermal Research, (2014). DOI: 10.1016/j.jvolgeores.2014.01.008

thick at the time the trees fell, and if this were the case the trees wouldn't have been incorporated and transported along the ground in the current. Thus the more reasonable interpretation is that the trees were snapped near their base by the early base surges.

Outcrops S1 and S2: PH1 is exposed on the northwest side of the tuff ring (S1-S2, Figures 3 and 5). Steeply-dipping dunes with bedding dips up to $36^{\circ}$, wavelengths from $10-15 \mathrm{~m}$, and amplitudes of less than a meter are exposed in plan-view at S1 (Figure 5a, d). Subangular to subrounded accidental blocks of siliciclastic origin (mudstones and sandstones) are common in this area and comprise 3-5\% of the deposits (Figure 5b, c). The five largest ballistic-emplaced blocks (measured in two dimensions along their longest axis) are between 25 by $15 \mathrm{~cm}$ and 39 by $15 \mathrm{~cm}$ (a full list of block sizes and types are documented in Table 2). No tree remnants were found in this region.

The outcrop at S2 is $0.75 \mathrm{~m}$ thick and composed of two new lithofacies, LT1 and TB1, which are not included in the general stratigraphy as they are found only in this proximal location (Figure 5e, f-i). LT1 and TB1 are massive, poorly-sorted lapilli tuff and tuff breccia that alternates from grain-supported (80-95\% juvenile coarse ash and lapilli, <5\% accidental clasts, and $<10 \%$ fine-medium ash matrix) to matrix-supported (10-20\% juvenile coarse ash or lapilli, $10-20 \%$ accidental lithics, $40-60 \%$ fine to medium ash). The massive, poorly sorted nature of the LT1-TB1 tuff breccia suggests local (near source) transport in a highly concentrated flow, such as a remobilized debris flow (e.g., lahar). This type of deposit is common in proximal regions of maar volcanoes and often occurs as syn-eruptive debris flow filled gullies (e.g., Nemeth and Cronin, 2007; Brand et al., 2008). This lithofacies is important to note here as its proximal nature suggests that the Maungataketake eruption may have been initiated on the northwest side 

resulting from the publishing process, such as peer review, editing, corrections, structural formatting, and other quality control mechanisms may not be reflected in this document. Changes may have been made to this work since it was submitted for publication. A definitive version was subsequently published in Journal of Volcanology and Geothermal Research, (2014). DOI: 10.1016/j.jvolgeores.2014.01.008

of the tuff ring. Lithofacies LT1-TB1 is overlain by finely laminated, centimeter-thick, stratified beds of PH1 (T2 and T4; Figure 5e, i).

Outcrops S3 and S4: The outcrop exposed between S3 and S4 is nearly perpendicular to the dominant direction of lateral pyroclastic transport. S4 is located 115 meters to the east-northeast of S3 (Figure 3). The basal contact between the organic-rich substrate and pyroclastic sequence is exposed along this outcrop (Figure 6a-d). The pyroclastic sequence begins with a 3.5 meterthick deposit of medium-gray-colored PH1 (Figure 6a-d), which thins to $1.8 \mathrm{~m}$ at location S4. The strata undulate, pinch and swell laterally, and are deformed or drape around obstacles (e.g., stumps and tree logs; e.g., Figure 6c-d). A striking 35 x $12 \mathrm{~cm}$ ballistic and $30 \mathrm{~cm}$ deep bedding plane sag that wraps around the ballistic illustrates the wet nature of the deposits at the time of deposition (Figure 6e; Table 2).

Rip up clasts of the organic-rich substrate and smaller tree trunks and tree fragments are abundant within the first meter of pyroclastic deposits (Figure 6b-d). The downed trees range from 20 to $42 \mathrm{~cm}$ in diameter and are most commonly found $25-40 \mathrm{~cm}$ above the basal contact (Figure $6 \mathrm{~b}, \mathrm{c}$ ). The roots of trees were not found within the deposits, suggesting that the trees may have been snapped rather than uprooted. The first standing tree (cast) is found roughly half way between S3 and S4. The cast is $20 \mathrm{~cm}$ in diameter and 2 meters tall. It is near-vertical but leaning towards the down-current direction. A second well-preserved tree is found in growth position at location $\mathrm{S} 4$. This tree is $55 \mathrm{~cm}$ in diameter, $\sim 2.5 \mathrm{~m}$ tall, and is also leaning in the down-current direction (Figure 6f).

Outcrops S5 and S6: Individual beds continue to thin and fine to the south. The basal contact between the organic-rich substrate and pyroclastic sequence is $\sim 0.2 \mathrm{~m}$ below the beach line at S6 and can only be observed at low tide. The deposits of PH1, which are $1 \mathrm{~m}$ thick in total, are 
NOTICE: this is the author's version of a work that was accepted for publication in Journal of Volcanology and Geothermal Research. Changes resulting from the publishing process, such as peer review, editing, corrections, structural formatting, and other quality control mechanisms may not be reflected in this document. Changes may have been made to this work since it was submitted for publication. A definitive version was subsequently published in Journal of Volcanology and Geothermal Research, (2014). DOI: 10.1016/j.jvolgeores.2014.01.008

bedded with $20 \mathrm{~cm}$ thick, fine-grained T1 lithofacies with reverse-graded, discontinuous coarseash horizons of T4 (Figure 7a-b). T1 alternates with 1-7 cm thick, finely laminated beds of T2. Interlaminations of 1-2 mm, dark juvenile clasts are common within T2. Reverse-graded interbeds of T4 occur but are less common in this location than more proximal outcrops. Tree trunks and fragments remain common in the first meter of the section. A $0.98 \mathrm{~m}$ tall tree stump with a basal diameter of $40 \mathrm{~cm}$ protruding from the base of the outcrop at $\mathrm{S} 5$ is preserved in growth position (Figure 7b). The bark around the outside of the tree is blackened and appears charred. Imbedded clasts were not found in the bark.

The current level of the surface above the beach outcrop continues to decrease to the southeast such that the contact between the pyroclastic sequence and paleo-surface is wellexposed at section $\mathrm{S6}$, which is a $0.75 \mathrm{~m}$ high wave-cut platform (Figure 8). Erosion has removed PH3; only $\sim 0.75 \mathrm{~m}$ of $\mathrm{PH} 1$ and the lower-most part of $\mathrm{PH} 2$ are exposed along the platform (Figure 8). Individual strata of T2 and T4 have fined and thinned such that the average overall grain size is fine to medium ash with the average coarsest grain size 1-2 mm; beds are 1-2 $\mathrm{cm}$ thick (Figure 8e). Accretionary lapilli are common in a few layers of lithofacies T2 and T4 (Figure 8f). Surface exposure reveals that these bedded deposits consist of low amplitude, long wavelength, symmetrical, bowl-shaped bedforms (Figure 8a). The bedforms have wavelengths of 1-3 meters, amplitudes of $10-30 \mathrm{~cm}$, and individual beds that dip a maximum of $10^{\circ}$. Beyond this location the deposits are poorly exposed in the tidal zone but appear to transition to nearly flat-lying, planar-wavy-bedded deposits (Figure 8d), eventually pinching out and/or disappearing beneath the tidal platform $\sim 0.6 \mathrm{~km}$ towards the southeast (off the map in Figure 3).

More than 30 tree casts from 19 to $56 \mathrm{~cm}$ in diameter are preserved along the platform of S6 in the lower PH1 within the intertidal zone. The average tree size is $20 \mathrm{~cm}$ in diameter, while 
NOTICE: this is the author's version of a work that was accepted for publication in Journal of Volcanology and Geothermal Research. Changes resulting from the publishing process, such as peer review, editing, corrections, structural formatting, and other quality control mechanisms may not be reflected in this document. Changes may have been made to this work since it was submitted for publication. A definitive version was subsequently published in Journal of Volcanology and Geothermal Research, (2014). DOI: 10.1016/j.jvolgeores.2014.01.008

the maximum diameter is $109 \mathrm{~cm}$ (Figure 8a-d, h). The deposits on the upstream side of the growth position tree casts dip upward at angles up to $38^{\circ}$, and dip down at angles up to $25^{\circ}$ on the downstream side of the obstacle (Figure 8b). Some tree casts indicate that the trees were slightly bent over in the downstream flow direction. Tree branches and fragments up to $10 \mathrm{~cm}$ in diameter are found within the basal deposits. Tiny root casts only $0.5-1 \mathrm{~cm}$ in diameter in growth position are also preserved (Figure $8 \mathrm{~g}$ ). A 1-3 $\mathrm{cm}$ thick, massive, muddy plaster coats the trees or is preserved on the rims of the tree casts (Figure 8g, h).

\section{Interpretation of Basal Base Surge Deposits and their Transport}

The thin, wavy stratified to cross-stratified beds and reverse-grading of PH1 suggests deposition from dilute, turbulent base surge currents where transport was dominated by grain saltation and traction sedimentation (e.g., Crowe and Fisher, 1973; Sohn and Chough, 1989; Branney and Kokelaar, 2002). This is further supported by the upward dip of beds upstream from obstacles, such as standing trees that were not toppled by the currents. The decrease in average grain size and thinning of the deposits with increasing distance from source suggests the currents were losing energy and carrying capacity as they traveled across the landscape, depositing coarser material proximal to source and finer material distal from source (e.g., Wohletz and Sheridan, 1979; Sohn and Chough, 1989). Incorporation of black, organic rich substrate suggests that the currents were erosive into the paleo-substrate. The well-sorted, laterally continuous beds of T4 could indicate a minor component of fallout.

The soft sediment deformation and tree casts coated in mud suggest the deposits were wet at the time of deposition, indicating three phase currents of gas, particles, and liquid water droplets (Fisher and Schmincke, 1984; Heiken and Wohletz, 1985; Brand and White, 2007; Brand and Clarke, 2009). This is further supported by the presence of accretionary lapilli and 
NOTICE: this is the author's version of a work that was accepted for publication in Journal of Volcanology and Geothermal Research. Changes resulting from the publishing process, such as peer review, editing, corrections, structural formatting, and other quality control mechanisms may not be reflected in this document. Changes may have been made to this work since it was submitted for publication. A definitive version was subsequently published in Journal of Volcanology and Geothermal Research, (2014). DOI: 10.1016/j.jvolgeores.2014.01.008

vesiculated tuff. However, tree bark exposed to the current(s) is scorched, suggesting that even though liquid water was present, the currents were sufficiently hot to char the outside of trees, which indicates the current must have been a minimum of $200^{\circ} \mathrm{C}$ (Browne, 1958).

The orientation of downed trees $>15 \mathrm{~cm}$ in diameter within $\mathrm{PH} 1$ were measured to constrain flow direction, and are plotted as rose diagrams in Figure 3 and Supplementary Table 3. The orientation of dipping beds against the tree casts at location S6 were also measured and plotted. The strongest signal is to the north-northwest, and is interpreted to reflect the dominant flow direction of the base surges produced early in the eruption. The orientation to the northeast is interpreted to be a result of branches perpendicular to the main trunks of downed trees and/or $\operatorname{logs}$ and branches that were rotated by the current at its base. Turbulent flow conditions, as are typically associated with base surges, commonly produce bimodal grain fabric with long-axis transverse-to-flow orientations due to particle rotation and parallel-to-flow orientations due to sliding within the current (e.g., Best, 1992; Capaccioni et al., 2001). Therefore the bimodality of the downed tree patterns is also consistent with transport in a turbulent flow.

\section{Initial Vent Location for PH1}

The crater rim is inferred from a digital elevation model (DEM) we produced from the Auckland Council LiDAR data (Figures 1 and 3). The rim measures $\sim 1 \mathrm{~km}$ northwest to southeast by $0.7 \mathrm{~km}$ southwest to northeast. As mentioned above, the LiDAR data suggests a nested tuff ring complex (Figure 3), which may indicate multiple vents, a migrating vent, or multiple episodes of varying scale during the phreatomagmatic phases of the eruption (as seen at Crater Hill, AVF; Houghton et al., 1996).

The final phase of the eruption produced the scoria cone roughly centered within this area, but the original location of the early vent, which would have been much smaller than the 
area within the presently preserved tuff ring, could have been anywhere within the extent of the tuff ring. While it is impossible to distinguish the initial vent location at the onset of eruption using the preserved surface expression of the volcanic center, several lines of evidence suggest it was (at least initially) towards to the northwest side of the tuff ring. Evidence for this includes: (1) the higher proportion of ballistic accidental blocks within PH1 at locations S1 and S2 (3-5\%) relative to sections along the southeast exposures $(<1 \%$; Table 2$)$; (2) the presence of coarsegrained LT1-TB1 deposits at S2, interpreted as a proximal debris flow lithofacies; (3) the flow direction as indicated on the rose diagrams (Figure 3); and (4) the long wavelength bedforms at S1 relative to S6 (Figures 3 and 6). Thus we infer a vent location in the northwest for the onset of the phreatomagmatic eruption (star in Figure 3), and use this as the source for estimating distance from vent for each outcrop (Table 2). We recognize that this can be applied only to the lowest stratigraphic unit, PH1, from which the evidence was derived. We also recognize that the exact location is impossible to determine, which introduces some error in our estimates of distance from source for each outcrop. However, constraining the vent location relative to each outcrop is necessary for the modeling described below. As such we make the assumption that our estimate, which is strongly based on field data, is reasonable for comparing model result estimates of dynamic pressures and runout distance.

\section{Estimating Base Surge Conditions - Dynamic Pressure}

The initial dilute PDCs produced during this eruption (PH1) snapped the podocarp trees up to $0.7-0.9 \mathrm{~km}$ from the proposed vent (location $\mathrm{S} 4$ is $\sim 0.7-0.9 \mathrm{~km}$ from the proposed vent), and left them standing beyond this point. We follow the methods of Clarke and Voight (2000) to calculate the dynamic pressure $\left(\mathrm{P}_{\mathrm{dyn}}\right.$; Equ. 1) necessary to knock down trees of this size and strength. 
$P_{d y n}=\frac{I \sigma_{\text {ult }, \text { yield }}}{r_{\text {tree }}^{2} h_{\text {tree }}^{2} C_{D}}$

where $\sigma_{\text {ult,yield }}$ is the yield strength of Podocarpus wood parallel to the grain (62 MPa Clifton,

1991), I is the moment of inertia $\left(I=\frac{\pi r_{\text {tree }}^{4}}{4}\right)$, and $r_{\text {tree }}$ and $h_{\text {tree }}$ are the radii and heights of the trees, respectively. The coefficient of drag, $\mathrm{C}_{\mathrm{D}}$, is related to the Reynolds number, $R e=\frac{2 r_{\text {tree }} u \beta}{\mu}$, where $\mathrm{u}$ is the velocity of the current, $\beta$ is the bulk density of the current and $\mu$ is the bulk viscosity of the current. A $C_{D}$ of 1.1 is appropriate for flow around cylinders with $10<\operatorname{Re}<$ 4x10 ${ }^{5}$ (Rae and Pope, 1984; Anderson, 1991; Panton, 1996), and as such is adopted for this approximation. For tree diameters of $0.3-0.5 \mathrm{~m}$ and estimated heights of $5-9 \mathrm{~m}$, Equ. 1 estimates that $\mathrm{P}_{\mathrm{dyn}}$ values between $12-35 \mathrm{kPa}$ are required to snap trees of this composition within $2 \mathrm{~m}$ of their bases. This calculation also implies that $\mathrm{P}_{\mathrm{dyn}}$ must have dropped below $12 \mathrm{kPa}$ after $0.9 \mathrm{~km}$ from source to leave the rest of the trees in growth position. These calculated values are consistent with previous work by Valentine (1998) which estimates that the $\mathrm{P}_{\text {dyn }}$ of pyroclastic currents varies from $0.1 \mathrm{kPa}-10^{4} \mathrm{kPa}$.

\section{Surge Propagation Model}

Given that PDC-producing eruptions are dangerous and difficult to observe, real-time measurements of emplacement velocity and subsequent study of corresponding deposit characteristics are rare to non-existent. Thus, real-time quantitative measurements of surge properties such as velocity, flow depth, and particle concentration, correlated with resulting deposit characteristics, are not readily available. As an alternative way to understand the link between surge dynamics and some deposit characteristics, we apply, with some modification, the model of Bursik and Woods (1996), for flow of and sedimentation from steady-state, radiallyspreading density currents. The original work of Bursik and Woods (1996) was applied to large, 
NOTICE: this is the author's version of a work that was accepted for publication in Journal of Volcanology and Geothermal Research. Changes resulting from the publishing process, such as peer review, editing, corrections, structural formatting, and other quality control mechanisms may not be reflected in this document. Changes may have been made to this work since it was submitted for publication. A definitive version was subsequently published in Journal of Volcanology and Geothermal Research, (2014). DOI: 10.1016/j.jvolgeores.2014.01.008

radially-spreading ash flows, and here we use the same approach to model the dynamics of radially-spreading base surges. Because both large ash flows (as in Bursik and Woods, 1996) and base surges are turbulent, particle-laden, density currents, the fundamental dynamics and governing equations are the same.

We recognize that evidence for liquid water at the time of deposition suggests wet, three phase flows, but at this point we do not have the ability to model this level of complexity. However, because they represent a small percentage of the total surge mass, liquid water droplets likely have only minor effects on the thermal and large-scale evolution of the currents (although they may influence depositional characteristics such as bedform morphology, e.g., Cole, 1991). As such, we do not directly account for the presence of water droplets in the currents. Similarly, we recognize that the deposits consist of a wide range of grain sizes and densities. Nonetheless, we simplify the model using a single grain size representative of the average of the juvenile component. We also assume dilute, incompressible flow at atmospheric pressure, and radial propagation away from source. Radial propagation in the case of base surges is a result of the collapse of discrete "cock's tail jets", "eruption slugs" and/or eruption columns as noted by several sets of observations, including those in Mastin and Witter (2000), Belousov and Belousova (2001), and Nemeth et al. (2006).

The model uses depth-averaged flow properties and assumes steady flow conditions in order to simplify the simulations. The depth-averaging does not assume that the flow is vertically uniform, but rather uses depth-averaged properties to calculate the macro-scale dynamics of the flow, as is often done for density currents with considerable success when the two criteria of shallow flow and hydrostatic pressure conditions are met (e.g., Takahashi 2001). Shallow flow conditions are met when the flow has much greater horizontal extent than vertical extent, which 
is the case with the base surges considered here. The hydrostatic pressure condition is met when the substrate slope is shallow and gently varying, as in the cases presented here. Vertical parameter variations can then be recovered if the form of the vertical profiles is known or can be approximated. Using a steady model to calculate the propagation characteristics of impulsive or short-lived density currents is justified by field observations of Karymskoye lake eruption and other similar eruptions (Belousov and Belousova 2001), which demonstrate that these types of flows are not released instantaneously. Rather, they are released over a finite period of time, during which time we can approximate the release as steady. The comparisons of model results to some well-documented cases (Sedan, Taal, Karymskoye lake) support this simplification and are discussed later and in supplementary material.

Despite these many simplifying assumptions, the model has captured the observations at Maungataketake (as demonstrated below) and has also allowed us to gain a better understanding of the first order controls on flow of and sedimentation from a dilute, radially spreading current. We have explicitly tested the effects of atmospheric entrainment, particle sedimentation, basal friction, initial temperature, and initial current thickness, and initial density on large-scale current dynamics.

The conservation of mass for a steady-state axisymmetric, vertically uniform flow is given by:

$\frac{d(\beta u h r)}{d r}=\varepsilon \alpha u r-S$

where $u$ is the current velocity, $h$ is the current depth, $r$ is the radial distance, and $\alpha$ is the ambient (air) density. The term on the left-hand side represents the downstream spatial gradient in mass flux. The terms on the right-hand side represent mass incorporated via entrainment and mass lost via sedimentation, respectively, both per unit depth. Bulk density $(\beta)$ of the current is given by 
$\beta=\left(\frac{n R T}{P}+\frac{1-n}{\rho_{s}}\right)^{-1}$

where $\rho_{\mathrm{s}}$ is the density of the solids, and $\mathrm{n}, \mathrm{R}, \mathrm{T}$ are the gas mass fraction, average gas constant for the flow and temperature of the magma, respectively. The entrainment coefficient ( $\varepsilon$ ) in Eq. 2 is a function of Richardson number (Ri), as in the empirical relationship of Parker et al. (1987), (consistent with Bursik and Woods, 1996).

$$
\varepsilon=\frac{0.075}{\left(1+718 R i^{2.4}\right)^{0.5}}
$$

The mass loss due to sedimentation is given by:

$S=-\frac{v_{S} M}{h u}$

where $M$ is the mass flux of particles $(M=(1-n) \beta u h r)$, and the settling velocity, $v_{s}$, is given by:

$v_{S} \cong\left(\frac{\rho_{s} g D_{P}}{C_{D} \beta}\right)^{1 / 2}$

where $D_{P}, \rho_{\mathrm{s}}$, and $C_{D}$ are the particle size, particle density, and coefficient of drag, respectively. $\left(C_{D}=1.1\right.$ for $10<\operatorname{Re}<\sim 4 \times 10^{5}$, e.g., Anderson, 1991). The sedimentation equation is based on Hazen's law (Hazen, 1904), which assumes that all particles are either fully in suspension and well-mixed or have settled, but does not account for traction transport at the interface between the density current and the ground. Hazen's law has been successfully applied and validated experimentally for sedimenting gravity currents (e.g., Woods and Bursik, 1994; Bonnecaze et al. 1993, 1995).

The conservation of momentum is:

$\frac{d \beta u^{2} h r}{d r}=(\beta-\alpha) g r h\left(-\frac{d h}{d r} \cos \theta+\sin \theta\right)-\frac{1}{2} g h^{2} r \frac{d \beta}{d r}-f u^{2} r \beta-u S$

where the left-hand side represents the downstream spatial gradient in momentum flux. The terms on the right-hand side containing $d h / d r$ and $d \beta / d r$ account for forces caused by 
downstream variations in current thickness and density, respectively. The second term on the right-hand side, containing $\sin \theta$, accounts for gravitational forces. The third term is a basal friction term where $\mathrm{f}$, the friction coefficient, accounts for surface roughness $(f=0.001-0.02$; Sparks et al., 1978; Bursik and Woods, 1996), and the fourth term accounts for loss of momentum due to sedimentation of solid particles (Equ. 6).

The energy equation is given by,

$\frac{d}{d r}\left(\beta u h r\left(c_{\text {mixture }} T+\frac{p}{\beta}+\frac{1}{2} u^{2}\right)\right)=\varepsilon \alpha u r\left(c_{a} T_{a}+\frac{p}{\alpha}\right)-S c_{S} T$

where the left-hand side represents the streamwise variation in energy flux, and $p$ is pressure, which we assume is equivalent to ambient pressure, $T_{0}$ is the initial temperature of the erupted material, $\mathrm{T}_{\mathrm{a}}$ is the temperature of the entrained air, and $c_{S}, c_{a}$, and $c_{p}$ are the specific heats of the solids (basalt), atmosphere, and current mixture, respectively (Table 4). This equation accounts for pressure variation and temperature changes due to atmospheric entrainment and settling of solid particles (right-hand side, Bursik and Woods, 1996). The specific heat of the current mixture is given by:

$c_{\text {mixture }}=n_{m} * c_{\text {watervapor }}+\left(n-n_{m}\right) * c_{a}+(1-n) c_{s}$

where $n_{m}$ is the volatile mass fraction of the magma, $c_{\text {watervapor }}$ is the specific heat of water vapor, assuming magmatic gas is primarily water vapor, and $n$ is the total gas mass fraction in the current. The initial total gas mass fraction is given by $n_{0}=\lambda+(1-\lambda) n_{m}$, where $\lambda$ is the mass fraction entrained by air. The initial temperature of the mixture is calculated by:

$T_{0}=\frac{(1-\lambda) c_{\text {mixture }} T_{0}+\lambda c_{a} T_{a}}{(1-\lambda) c_{\text {mixture }}+\lambda c_{a}}$

The applicability of this model to radially-spreading base surges is demonstrated in Supplementary Figures 1 and 2, which show that the model closely approximates the current 
velocity as a function of distance from source and run-out distance for the 1962 Sedan weapons test (Moore 1967). The model also reasonably predicts the deposit distribution for the 1965 eruption of Taal and the 1996 eruption at Karymskoye Lake, using well-constrained grain-size characteristics and observations (Moore 1967; Belousov and Belousova 2001) and assuming that sedimentation rate is a reasonable proxy for deposit distribution.

\section{Application of model to base surges from Maungataketake}

Using this model, we attempt to match flow dynamic pressures at varyious distances and deposit extent for PH1 of the Maungataketake phreatomagmatic field case by varying initial thickness, initial velocity and bulk density over a reasonable range. Input parameters are listed in Table 4. The well-bedded and cross-stratified nature of the PH1 deposits suggest emplacement via base surges where a combination of traction and turbulent transport occurred, suggesting partially to fully dilute currents (Branney and Kokelaar, 2002). Pyroclastic currents with mixture bulk densities $<20 \mathrm{~kg} \mathrm{~m}^{-3}$ are considered to be in the dilute regime (Wohletz, 1998). However, initial mixture bulk densities may have been higher, but would rapidly decrease to the dilute regime with distance from source due to sedimentation of particles and entrainment of ambient atmosphere.

The average particle size for the deposits at Maungataketake varies amongst lithofacies within PH1 from fine ash to fine lapilli. We assume an average grain size of $0.5 \mathrm{~mm}$ best represents the package as a whole, despite the fact that some beds within the package were finergrained and some coarser-grained. The effects of a range of particles sizes on flow dynamics are explored later in this paper. The paleo-surface gently undulates (Marra et al., 2006) and has a low to negligible slope ( one degree), thus we adopt this value for our model. Clast density is taken as $2700 \mathrm{~kg} \mathrm{~m}^{-3}$ and volatile mass fraction is assumed to be 0.02 , as these values are typical 
NOTICE: this is the author's version of a work that was accepted for publication in Journal of Volcanology and Geothermal Research. Changes resulting from the publishing process, such as peer review, editing, corrections, structural formatting, and other quality control mechanisms may not be reflected in this document. Changes may have been made to this work since it was submitted for publication. A definitive version was subsequently published in Journal of Volcanology and Geothermal Research, (2014). DOI: 10.1016/j.jvolgeores.2014.01.008

for basalt (Table 4). Magmatic temperatures for basalt are $\sim 1473 \mathrm{~K}$; however, the interaction with external water at the time of fragmentation would have lowered the initial temperature of the pyroclasts. The PHM program, designed to calculate thermodynamic values for phreatomagmatic eruptions (Kware PHM copyright 2007) predicts temperatures of $741-822 \mathrm{~K}$ for magma-water ratios between 0.3 - 0.4 (input parameters to PHM include initial magma temperature of $1473 \mathrm{~K}$, water temperature of $298 \mathrm{~K}$, initial and ambient pressures of $0.1 \mathrm{MPa}$ ). This range of temperatures is supported by the identification of charred wood found $>1 \mathrm{~km}$ from source (Location S5), which indicates that surge temperatures were at least $473 \mathrm{~K}$ after cooling during transport from source to Location S5. We thus use this range of values as the initial mixture temperature in the density propagation model described above. The average gas constant for water vapor, which is assumed to be the dominant volatile component, is $462 \mathrm{~J} \mathrm{~kg}^{-1} \mathrm{~K}$ (e.g., Bursik and Woods, 1996).

Initial velocities of 50-100 $\mathrm{m} \mathrm{s}^{-1}$ correspond to a column collapse height of $\sim 125-500 \mathrm{~m}$ according to Bernoulli's principle, which ignores pressure variations over height variations of a few hundred meters $\left(u=\sqrt{\frac{1}{2} g h_{\text {collapse }}}\right.$ where $h_{\text {collapse }}$ is the column collapse height). These are reasonable values based on rare observed velocity estimates for base surges (Moore, 1967; Belousov and Belousova, 2001) and column collapses from phreatomagmatic eruptions (50-200 m for Ambae Islands, Vanuatu, Nemeth et al., 2006; 250 m for Karymoskoye Lake eruption, Kamchatka, Belousov and Belousova, 2001; estimates of up to $>2 \mathrm{~km}$ for Table Rock Complex Eruption 2, Brand and Clarke, 2012). The initial radius, $\mathrm{r}_{0}$, is assumed to be $200 \mathrm{~m}$ from source, which we regard as reasonable for a collapsing column.

The two main criteria for model success based on the field evidence are (a) $\mathrm{P}_{\text {dyn }}$ must be $>12 \mathrm{kPa}$ prior to $0.9 \mathrm{~km}$, and $<12 \mathrm{kPa}$ beyond $0.9 \mathrm{~km}$ to explain the blow-down pattern of 
Podocarpus totara trees; and (b) total run-out distance must be at least $1.8 \mathrm{~km}$, although it is possible that the currents traveled further and the distal-most deposits are not exposed. $\mathrm{P}_{\mathrm{dyn}}$ of PDCs is a function of bulk density and velocity (Equation 1), which can be calculated for any given distance from source by the model. By varying initial conditions we found initial velocities of $65 \mathrm{~m} \mathrm{~s}^{-1}$, initial bulk densities of $38 \mathrm{~kg} \mathrm{~m}^{-3}$ and initial current thickness of $60 \mathrm{~m}$ reproduce the best fit to our field data (Table 3; Figure 9). Figure 9 illustrates that, given these initial conditions, run-out distance is calculated to be $2.25-2.35 \mathrm{~km}$ and $\mathrm{P}_{\mathrm{dyn}}$ is $11.6-12.2 \mathrm{kPa}$ at $0.9 \mathrm{~km}$ from source, and $<12 \mathrm{kPa}$ past $0.9 \mathrm{~km}$, consistent with field estimates based on tree blow down patterns.

Figure 9 illustrates the loss of bulk density due to sedimentation of particles and entrainment of air as the current moves away from source. The slight initial acceleration is a result of a decrease in current thickness as the current spreads radially (Figure 9). The velocity begins to decelerate as the current thickens due to ambient entrainment. Note that the velocity does not go to zero; rather the current stops moving laterally when the bulk density is equivalent to the atmospheric density. We can interpret this location to be the point of lift-off, where ground-parallel velocity transitions to vertical velocity by means of a buoyant plume, as is common in PDCs and base surges (i.e., Woods and Bursik, 1994; Belousov and Belousova, 2001). With these conditions, $\mathrm{P}_{\mathrm{dyn}}$ up to $80 \mathrm{kPa}$ can be expected closer to the vent (within 0.5 $\mathrm{km})$.

\section{Discussion}

These results illustrate our ability to reproduce field observations and interpretations with the modeling techniques described above. The $\mathrm{P}_{\mathrm{dyn}}$ of PDCs can vary from $0.1 \mathrm{kPa}-10^{4} \mathrm{kPa}$ for pyroclastic currents (Valentine, 1998). The tree blow down pattern from Maungataketake 
NOTICE: this is the author's version of a work that was accepted for publication in Journal of Volcanology and Geothermal Research. Changes resulting from the publishing process, such as peer review, editing, corrections, structural formatting, and other quality control mechanisms may not be reflected in this document. Changes may have been made to this work since it was submitted for publication. A definitive version was subsequently published in Journal of Volcanology and Geothermal Research, (2014). DOI: 10.1016/j.jvolgeores.2014.01.008

suggests the dilute currents of PH1 were on the lower end of this range. Now that reasonable parameters have been established for the currents responsible for the PH1 deposits, the senstitivy of model results to parameters such as initial current thickness, initial velocity, initial bulk density, grain size, slope and friction coefficient are tested to elucidate those that have a dominant control on current behavior and evolution with distance from source, and to illustrate the parameters most important to constrain for modeling natural events in a predictive capacity (Table 3). We vary one parameter at a time while holding all other variables constant, thus demonstrating first-order controls on dilute PDC dynamics.

The two main processes controlling the runout distance of a given PDC are the sedimentation rate (Equation 6) and entrainment of ambient atmosphere (Equations 4-5), both of which act to reduce current density. Sedimentation and entrainment are heavily influenced by the initial bulk density, thickness and velocity of a given current. First we explore the influence of initial bulk density. Lower initial bulk densities, all else being equal, result in shorter run-out distances, greater rates of entrainment, a more rapid deceleration of the current and lower $P_{d y n}$ (Figure 10). This relationship is intuitive as it is expected that initially denser flows are capable of maintaining their momentum and density contrast over greater distances. $\mathrm{P}_{\mathrm{dyn}}$ in all cases drops off quickly as the current bulk density and velocity decrease due to sedimentation and entrainment with distance from source (Figure 10), while initially denser currents maintain higher $\mathrm{P}_{\mathrm{dyn}}$ further from source, as expected. By exploring this range we find that $\beta \approx 38 \mathrm{~kg} \mathrm{~m}^{-3}$ produces both the run-out distance measured in the field and the estimates for $\mathrm{P}_{\mathrm{dyn}}$, as discussed above and demonstrated in Figure 10.

Vent mass flux controls column collapse height, which to great extent controls the total amount of entrained ambient air before collapse (more entrainment with higher collapse heights). 
NOTICE: this is the author's version of a work that was accepted for publication in Journal of Volcanology and Geothermal Research. Changes resulting from the publishing process, such as peer review, editing, corrections, structural formatting, and other quality control mechanisms may not be reflected in this document. Changes may have been made to this work since it was submitted for publication. A definitive version was subsequently published in Journal of Volcanology and Geothermal Research, (2014). DOI: 10.1016/j.jvolgeores.2014.01.008

Because of this relationship, initial current thickness is controlled to great extent by vent mass flux, which depends upon vent velocity and clast concentration. However, the exact relationship between these initial conditions and initial current thickness is poorly constrained. We therefore explore initial current thicknesses (h) over a range of $30 \mathrm{~m}$ to $200 \mathrm{~m}$, which is reasonable for the range of column collapse heights considered above (again holding all other variables constant). For most cases a decrease in current thickness occurs due to the initial radial spreading, which coincides with a brief acceleration of the current (Figure 11). As the current(s) travel away from source they thicken due to entrainment, causing a deceleration of the current and an increase in sedimentation rate, which eventually leads to lift-off of the current. We note that initially thicker currents, for fixed other properties, result in a protracted thinning zone, causing greater initial acceleration and greater runout distance (e.g., $\mathrm{h}=100 \mathrm{~m}$; third plot in Figure 11). The distance over which high dynamic pressures are maintained also increases with higher initial current thickness, likely due to the more gradual decrease in bulk density due to less rapid entrainment of air and slower sedimentation rates (e.g., Bursik and Woods, 1996).

Initial velocity does not have a strong influence on run-out distance (Figure 11). Higher initial velocities result in high entrainment rates, which cause the current to thicken more rapidly than currents with lower initial velocities (Figure 12). Greater entrainment of ambient air for high initial velocities results in runout distances similar to those with relatively low initial velocities (as also demonstrated in Bursik and Woods, 1996). However, higher initial velocities do affect $\mathrm{P}_{\mathrm{dyn}}$, resulting in a more gradual decrease in $\mathrm{P}_{\mathrm{dyn}}$ with distance from source.

Grain size has a moderate effect on overall dynamics. Increasing the grain size causes the current to slow and the mixture bulk density to decline more quickly, and results in shorter runout distances, due to a higher sedimentation rates (see Table 3 for a range of grain sizes; 
NOTICE: this is the author's version of a work that was accepted for publication in Journal of Volcanology and Geothermal Research. Changes resulting from the publishing process, such as peer review, editing, corrections, structural formatting, and other quality control mechanisms may not be reflected in this document. Changes may have been made to this work since it was submitted for publication. A definitive version was subsequently published in Journal of Volcanology and Geothermal Research, (2014). DOI: 10.1016/j.jvolgeores.2014.01.008

Supplementary Figure 3). However, relative to the three parameters explored above, grain size, within the range of grain sizes documented at Maungataketake, has a lesser effect on overall current dynamics.

Slope, on the other hand, has a significant influence on flow dynamics (see Table 3 for a range of slopes; Supplementary Figure 4). Increasing slope causes the current to become more supercritical (lower Ri numbers) more quickly, which increases the rate of entrainment and decreases run-out distance. As such, increasing slopes leads to decreasing run-out distance for a given current. Dynamic pressure is relatively unaffected by grain size and substrate slope.

Finally, we chose a high friction coefficient $(f)$ due to obvious interaction with a small forest. While $f$ does not influence $\mathrm{P}_{\mathrm{dyn}}$, higher $f$ forces the current to slow more quickly due to frictional losses at the base. Lower $f$ causes the current to slow less quickly and in some conditions accelerate, resulting in a more rapid rate of entrainment of ambient air resulting in shorter run-out distances than higher friction coefficients, which is somewhat counterintuitive. Higher values of $f$, which are more reasonable for Maungataketake given the known interaction with a forest, produce velocity profiles that initially accelerate then decelerate towards the distal end of the flow (Supplementary Figure 5). 
NOTICE: this is the author's version of a work that was accepted for publication in Journal of Volcanology and Geothermal Research. Changes resulting from the publishing process, such as peer review, editing, corrections, structural formatting, and other quality control mechanisms may not be reflected in this document. Changes may have been made to this work since it was submitted for publication. A definitive version was subsequently published in Journal of Volcanology and Geothermal Research, (2014). DOI: 10.1016/j.jvolgeores.2014.01.008

Exploring this parameter space has allowed us to determine the combination of initial bulk density, velocity and current thickness that most accurately reproduce the base surges that occurred during the early stages of the Maungataketake eruption. We have also demonstrated how exploring parameter space can provide understanding of first-order controls on base surge dynamics. Next we explore the implications of our results with regards to the hazard potential within the AVF.

\section{Implications for the AVF}

AVF eruptions can be magmatic or phreatomagmatic, although most centers in the field show both styles of eruption within their depositional record (Smith and Allen, 1993; Allen and Smith, 1994). Most eruptions begin as phreatomagmatic events and either stop after this phase, resulting in maars and tuff rings, or gradually evolve into magmatic eruptions as the influence of external water decreases, resulting in Hawaiian-style lava fountaining to Strombolian style eruptions that build cinder/scoria cones and/or produce lava flows (Allen and Smith, 1994; Sandri et al., 2012). It is still not possible to predict exactly where the next eruption may occur, however the higher sea level and saturated regional aquifers within the Miocene bedrock and Pliocene sediments beneath Auckland increase the chances that an eruption within this area will have a base-surge producing, phreatomagmatic phase (Sandri et al., 2012; Le Corvec et al., 2013a, b). Base surges produced from a phreatomagmatic eruption in this region could devastate a radius of 1-6 km from the volcanic center depending on the size of the eruption (e.g., Sandri et al., 2012).

$\mathrm{P}_{\mathrm{dyn}}$ is a function of the bulk density of a current, controlled by the particle concentration, and the square of the current's velocity (Equation 1). PDCs can have particle concentrations ranging from $10^{-3}$ to 0.5 and velocities ranging from 10 to $300 \mathrm{~m} \mathrm{~s}^{-1}$ (Valentine, 1998) resulting 
NOTICE: this is the author's version of a work that was accepted for publication in Journal of Volcanology and Geothermal Research. Changes resulting from the publishing process, such as peer review, editing, corrections, structural formatting, and other quality control mechanisms may not be reflected in this document. Changes may have been made to this work since it was submitted for publication. A definitive version was subsequently published in Journal of Volcanology and Geothermal Research, (2014). DOI: 10.1016/j.jvolgeores.2014.01.008

in $\mathrm{P}_{\mathrm{dyn}}$ from 1 to $10^{4} \mathrm{kPa}$. Dilute PDCs, such as base surges, typically have particle concentrations $<10^{-1}$ by volume and thus have a lower $\mathrm{P}_{\mathrm{dyn}}$ than more concentrated end-members (Wohletz, 1998). However, particles often concentrate in the lower portion of the current, thus $\mathrm{P}_{\mathrm{dyn}}$ for the bedload region can be expected to be much higher than for a well-mixed portion of the current above (Valentine, 1987). This particle distribution implies that $\mathrm{P}_{\mathrm{dyn}}$ may be higher than the average values predicted by the depth-averaged models presented here, motivating future work in this area. We must also consider that temperature, dynamic pressure and hot fine ash have lethal effects on population, even with dilute regimes of $0.1 \%$ particles by volume (Baxter et al., 1998; Dellino et al., 2008), thus even if infrastructure survives the passing of a base surge the fatality rate may be high for those experiencing direct exposure (Baxter et al., 2005).

Valentine (1998) uses air shock overpressures as an analog for dynamic overpressure effects of PDCs, neglecting thermal effects. The onset of structural damage begins around $7 \mathrm{kPa}$. Heavy, steel-framed, reinforced buildings and masonry or precast concrete houses withstand structural damage, but lighter steel-framed buildings and wood houses will likely experience more damage, especially at $\mathrm{P}_{\mathrm{dyn}}$ between 10 and $14 \mathrm{kPa}$. Windows, weak partitions and aluminum or steel wall panels will likely be destroyed. Roads and railways would be relatively unaffected. Structural damage will be more severe for $\mathrm{P}_{\mathrm{dyn}}$ between 20 and $30 \mathrm{kPa}$. Steel-frames may be bent or partially pulled out of their footings. Weaker buildings, such as those with light panels or wood-frame houses, would be damaged beyond repair or destroyed. Damage to trains could render them unusable; vehicles would be displaced but potentially functional. $\mathrm{P}_{\mathrm{dyn}}>35 \mathrm{kPa}$ would result in near total destruction except for buildings built to withstand earthquakes or 
NOTICE: this is the author's version of a work that was accepted for publication in Journal of Volcanology and Geothermal Research. Changes resulting from the publishing process, such as peer review, editing, corrections, structural formatting, and other quality control mechanisms may not be reflected in this document. Changes may have been made to this work since it was submitted for publication. A definitive version was subsequently published in Journal of Volcanology and Geothermal Research, (2014). DOI: 10.1016/j.jvolgeores.2014.01.008

single-story, low-profile buildings with precast concrete slabs for walls and flat roofs. Most vehicles and trains would be destroyed.

Baxter et al. (2005) assess the damage to structures from dilute PDCs generated during the 1997 eruptions of Soufrière Hills volcano, Montserrat, to understand the main causes of damage from PDCs and building vulnerability. Their study clearly shows that the impact of projectiles consisting of lapilli, blocks, entrained trees or building materials can significantly add to the damage potential of PDCs. As such the damage inflicted to structures can be greater at lower $\mathrm{P}_{\mathrm{dyn}}$ than those estimated from the Valentine (1998) study. Baxter et al. (2005) suggest total destruction for $\mathrm{P}_{\mathrm{dyn}}>25 \mathrm{kPa}$, widespread damage to masonry buildings and complete destruction of weaker buildings for $\mathrm{P}_{\text {dyn }}$ between 8 and $25 \mathrm{kPa}$, moderate to serious damage to masonry buildings and collapse of some weaker buildings at $\mathrm{P}_{\mathrm{dyn}}$ between 4 and $10 \mathrm{kPa}$, damage to aluminum window and door frames but no structural damage at $\mathrm{P}_{\mathrm{dyn}}$ between 2 and $6 \mathrm{kPa}$, and damage only to window panes and other weak portions of structures at $\mathrm{P}_{\mathrm{dyn}}<3 \mathrm{kPa}$. Baxter et al. (2005) also show that the heat of the ash igniting flammable materials within homes increased damage in distal areas where the $\mathrm{P}_{\mathrm{dyn}}$ was negligible.

The Valentine (1998) and Baxter et al. (2005) studies serve as first-order approximations for the damage potential from PDCs, and are applied here to assess the damage potential for base surges from small, moderate and large eruptions in the AVF. The Maungataketake eruption is likely to represent events on the smaller side of possible phreatomagmatic eruptions in the AVF (Sandri et al., 2012; Kereszturi et al., submitted). However, $\mathrm{P}_{\mathrm{dyn}}$ from 35 to $60 \mathrm{kPa}$ can be expected within $0.5 \mathrm{~km}$ of the vent. $\mathrm{P}_{\text {dyn }}$ drops quickly as a function of dilution via sedimentation and entrainment with distance from source, reaching less than $10 \mathrm{kPa}>1 \mathrm{~km}$ from the vent. Virtually everything within $1 \mathrm{~km}$ from the vent would undergo some structural damage to 
NOTICE: this is the author's version of a work that was accepted for publication in Journal of Volcanology and Geothermal Research. Changes resulting from the publishing process, such as peer review, editing, corrections, structural formatting, and other quality control mechanisms may not be reflected in this document. Changes may have been made to this work since it was submitted for publication. A definitive version was subsequently published in Journal of Volcanology and Geothermal Research, (2014). DOI: 10.1016/j.jvolgeores.2014.01.008

complete destruction depending on the shielding effects of obstacles and topography and how quickly $\mathrm{P}_{\mathrm{dyn}}$ decreases; all weaker structures would be destroyed. Reinforced structures beyond $1 \mathrm{~km}$ may avoid structural damage, whereas weaker structures may still be affected by the $\mathrm{P}_{\mathrm{dyn}}$. Damage due to fires caused by the ash can be expected across the extent of the flow, especially for structures with a large portion of unprotected, open windows (Baxter et al., 2005).

We explore a range of initial bulk densities, column collapse heights and initial velocities for a range of possible eruptions within the AVF. We explore column collapse heights of 330$1000 \mathrm{~m}$, resulting in initial velocities of $80-140 \mathrm{~m} \mathrm{~s}^{-1}$ using the modified Bernoulli equation, as discussed earlier in this paper, and initial flow thicknesses up to $200 \mathrm{~m}$ (Table 4).

We first explore the effect of an "average" eruption, an eruption that produces base surges with runout distances of 2-4 km (parameters given in Table 4; Figure 13). Base surges can be expected to have $\mathrm{P}_{\mathrm{dyn}}$ from 10 to $160 \mathrm{kPa}$ within $1 \mathrm{~km}$ of the vent, dropping to $<12 \mathrm{kPa}$ at $2 \mathrm{~km}$, and decreasing to $<5 \mathrm{kPa}$ towards the final runout distance of $4 \mathrm{~km}$ (Figure 13). Thus for an average eruption, complete destruction can be expected within $1.5 \mathrm{~km}$ from the vent, heavy damage to reinforced structures up to $2 \mathrm{~km}$ from the vent, and moderate damage to reinforced buildings and severe damage to weaker structures up to $3 \mathrm{~km}$ from vent. Damage to structures with windows and openings oriented perpendicular to the flow direction may experience fire damage due to infiltration of hot ash.

The "worst-case scenario" is one in which a base surge travels 4-6 km from source (e.g., Taal, Moore, 1967; TRC2, Brand and Clarke, 2009; Sandri et al., 2012; Table 5; Figure 14). In this case $\mathrm{P}_{\mathrm{dyn}}$ of up to $35 \mathrm{kPa}$ can be expected up to $2.5 \mathrm{~km}$ from source, ensuring complete destruction to the area (Figure 14). $\mathrm{P}_{\mathrm{dyn}}>15 \mathrm{kPa}$ is expected up to $4 \mathrm{~km}$ from source, which would results in heavy structural damage to most buildings and near destruction for weaker 
buildings. $\mathrm{P}_{\text {dyn }}$ decays to $<5 \mathrm{kPa}$ at $\sim 6 \mathrm{~km}$ from source, but damage to weaker structures can be expected over these distances.

\section{Conclusion}

This work illustrates the potential for combining field observations with numerical methods to constrain current dynamics and damage potential for dilute PDCs. The Maungataketake eruption represents one of the smaller-sized phreatomagmatic eruptions in the AVF. Base surges produced during the eruption traveled up to $1.8 \mathrm{~km}$ from source, toppling a small forest up to $0.9 \mathrm{~km}$ from source. This indicates dynamic pressures of $>12 \mathrm{kPa}$ up to this distance, decaying to $<12 \mathrm{kPa}$ towards the final runout distance of $\sim 2.25 \mathrm{~km}$. Our numerical modeling effort reproduces these conditions when initial velocity is $65 \mathrm{~m} \mathrm{~s}^{-1}$, initial bulk density is $38 \mathrm{~kg} \mathrm{~m}^{-3}$ and initial current thickness is $65 \mathrm{~m}$, serving to illustrate our ability to incorporate field observations and numerical techniques to explore depositional mechanisms, first-order controls on current dynamics, and potential impact of dilute PDCs.

The two main factors controlling the runout distance of a given PDC are the sedimentation rate and entrainment of ambient atmosphere, both of which act to dilute the current. Sedimentation and entrainment are heavily influenced by the initial bulk density, initial flow thickness, initial velocity, grain size, slope and friction coefficient. By testing the senstitivy of these parameters on current behaviour and evolution, we reach conclusions that are consistent with the previous findings of Bursik and Woods (1996) and observations of the Maungataketake deposits, and consequent inferences about AVF eruption dynamics:

1. Lower initial bulk densities result in shorter run-out distances, greater rates of entrainment, a more rapid deceleration of the current, and lower $\mathrm{P}_{\mathrm{dyn}}$. 
2. A decrease in current thickness occurs due to the initial radial spreading, coinciding with a brief acceleration of the current. As the current(s) travel away from source they thicken due to entrainment, which along with the geometric effect of spreading, causes a deceleration of the current and an increase in sedimentation rate, which ultimately leads to current cessation. Initially thicker currents result in a longer thinning zone during radial spreading, causing greater initial increase in velocity and greater runout distances. The distance over which $\mathrm{P}_{\mathrm{dyn}}$ remains high also increases with higher initial current thickness.

3. Initial velocity does not have a strong influence on run-out distance. Higher initial velocities result in high entrainment coefficients, which cause the current to thicken more rapidly than for lower velocities, resulting in runout distances similar to or lower than those for flows with lower initial velocities. However, higher initial velocities do increase $\mathrm{P}_{\mathrm{dyn}}$, resulting in a more gradual decrease in $\mathrm{P}_{\mathrm{dyn}}$ with distance from source.

4. Similar to higher velocities, increasing slope causes the current to become more supercritical closer to source, which increases the rate of entrainment. As such increasing slopes leads to decreasing run-out distance for a given set of initial conditions.

This work also illustrates how models such as this can be cautiously extrapolated as a predictive tool to assess the damage potential of future eruptions. We apply our model to "average" scenarios with base surge runout distances up to $4 \mathrm{~km}$, and "worst-case scenarios" with runout distances of 4-6 km, and explore the range of $P_{d y n}$ that result from these scenarios. For the "average" scenario near complete destruction can be expected within $0.5 \mathrm{~km}$ from the 
NOTICE: this is the author's version of a work that was accepted for publication in Journal of Volcanology and Geothermal Research. Changes resulting from the publishing process, such as peer review, editing, corrections, structural formatting, and other quality control mechanisms may not be reflected in this document. Changes may have been made to this work since it was submitted for publication. A definitive version was subsequently published in Journal of Volcanology and Geothermal Research, (2014). DOI: 10.1016/j.jvolgeores.2014.01.008

vent. Beyond this the $\mathrm{P}_{\mathrm{dyn}}$ decreases rapidly due to sedimentation and slowing of the current.

Moderate destruction can be expected up to $2 \mathrm{~km}$, but much less damage is expected up to the

final runout distance of $4 \mathrm{~km}$, although hot ash may still cause damage due to igniting flammable materials (e.g., Baxter et al., 2005). The "worst-case scenario" eruption would ensure complete destruction up to $2.5 \mathrm{~km}$ from source, severe damage to most structures up to $4 \mathrm{~km}$ from source, and moderate damage to reinforced structures and some damage to weaker structures up to $6 \mathrm{~km}$ from source.

Future modeling efforts should explore the effect of multiple grain sizes and the development of a more concentrated basal region within a density stratified flow. The more concentrated region would have a higher $\mathrm{P}_{\mathrm{dyn}}$ that may not decrease as rapidly as the depthaveraged dynamic pressure. The influence of multiple structures on flow dynamics should also be explored to understand the effects of shielding of upstream obstacles on downstream obstacles, and the control this increased surface roughness has on sedimentation and runout distance.

\section{Acknowledgements:}

The project was supported through the Determining volcanic risk in Auckland (DEVORA) project. 


\section{References}

Agustín-Flores, J., Németh, K., Cronin, S.J., Lindsay, J.M., Kereszturi, G., Smith, I.E.M. (submitted) Excavation not fragmentation: insights into basaltic phreatomagmatic eruptions through unconsolidated coastal plain sequences, Maungataketake tuff ring, Auckland Volcanic Field (New Zealand). . J. Volcanol. Geotherm. Res.

Allen, S.R., Smith, I.E.M., 1994. Eruption styles and volcanic hazard in the Auckland Volcanic Field, New Zealand. Geosci Rep Shizuoka Univ 20:5-14

Anderson, J.D., 1991. Fundamentals of Aerodynamics. McGraw-Hill, New York, 772 pp.

Baxter PJ, Neri A, Todesco M (1998) Physical modelling and human survival in pyroclastic flows. Nat Hazards 17:163-176

Bebbington, M.S., Cronin, S.J., 2011. Spatio-temporal hazard estimation in the Auckland Volcanic Field, New Zealand, with a new event-order model. Bull Volcanol 73:55-72.

Belousov, A. and Belousova, M., 2001. Eruptive process, effects and deposits of the 1996 and the ancient basaltic phreatomagmatic eruptions in Karymskoye Lake, Kamchatka, Russia. Spec. Pub. Intern. Assoc. Sediment. 30:35-60.

Best, J.L., 1992. Sedimentology and event timing of a catastrophic volcaniclastic mass flow. Volcan Hudson, Chile. Bull. Volcanol. 54:299-318.

Bonnecaze, R.T., Huppert, H.E., Lister, J.R. 1993. Particle-driven gravity currents. J. Fluid Mech. 250:339-369.

Bonnecaze, R.T., Hallworth, M.A., Huppert, H.E., Lister, J.R. 1995. Axisymmetric particledriven gravity currents. J. Fluid Mech. 294:99-121.

Brand, B.D., White, C.M., 2007. Origin and stratigraphy of phreatomagmatic deposits at the Pleistocene Sinker Butte Volcano, Western Snake River Plain, Idaho. J. Volcanol. Geotherm. Res. 160, 319-339.

Brand, B.D. and Clarke, A.B, 2009. The architecture, eruptive history, and evolution of the Table Rock Complex, Oregon: from a Surtseyan to an energetic maar eruption, J. Volcanol. Geotherm. Res. 180, 203-224.

Brand, B.D., and Heiken, G., 2009. Tuff cones, tuff rings, and maars of the Fort Rock-Christmas Valley Basin, Oregon: Exploring the vast array of pyroclastic features that record violent hydrovolcanism at Fort Rock and the Table Rock Complex, in: O'Connor, J.E., Dorsey, R.J., and Madin, I.P., eds., Volcanoes to Vineyards: Geologic Field Trips through the Dynamic Landscape of the Pacific Northwest: Geological Society of America Field Guide. 15, 1-18. 
NOTICE: this is the author's version of a work that was accepted for publication in Journal of Volcanology and Geothermal Research. Changes resulting from the publishing process, such as peer review, editing, corrections, structural formatting, and other quality control mechanisms may not be reflected in this document. Changes may have been made to this work since it was submitted for publication. A definitive version was subsequently published in Journal of Volcanology and Geothermal Research, (2014). DOI: 10.1016/j.jvolgeores.2014.01.008

Brand, B.D., Semken, S., Clarke, A.B., 2008. Eruptive Conditions and Depositional Processes of Narbona Pass Maar Volcano, Navajo Volcanic Field, Navajo Nation, New Mexico (USA). Bull.Volcanol. 71, 49-77.

Brand B.D., Clarke, A.B., 2012. An Energetic Basaltic Phreatomagmatic Eruption at the Table Rock Complex in South-central Oregon (USA): Using deposit characteristics to constrain surge dynamics. J. Volcanol. Geotherm. Res. 243-244:81-90.

Branney, M.J., Kokelaar P., 2002. Pyroclastic density currents and the sedimentation of ignimbrites. Memoir - Geological Society of London 27: 143.

Büttner, R., Zimanowski, B., 1998. Physics of thermohydraulic explosions. Physical Review Letters 57: 5726-5792.

Bursik, M.I., Woods, A.W., 1996. The dynamics and thermodynamics of large ash flows. Bull Volcanol 58:175-193.

Brothers, R.N., Golson, J., 1959. Geological and archaeological interpretation of a section in Rangitoto ash on Motutapu island, Auckland. N. Z. J. Geol. Geophys. 2:569-577.

Browne, F.L., 1958. Theories of the combustion of wood and its control: A survey of the literature. Forest Products Laboratory - U.S. forest Service Research Legacy. Rept. No 2136.

Capaccioni, B., Nappi, G., Valentini, L. 2001. Directional fabric measurements: an investigative approach to transport and depositional mechanisms in pyroclastic flows. J. Volcanol. Geotherm. Res. 107:275-292.

Clarke, A.B., Voight, B., 2000. Pyroclastic current dynamic pressure from aerodynamics of tree or pole blow-down. J. Volcanol. Geotherm. Res. 100:395-412.

Clifton, N.C. (1991) New Zealand Timbers - the complete guide to exotic and indigenous woods. Revised Edition. GP Publications: Wellington.

Cole, P.D. 1991. Migration direction of sand-wave structures in pyroclastic-surge deposits; implications for depositional processes. Geology (Boulder) 19:11: 1108-1111.

Crowe, B.M., Fisher, R.V., 1973. Sedimentary structures in base-surge deposits with special reference to cross-bedding, Ubehebe Craters, Death Valley, California. Geol. Soc. Am. Bull. 84, 663-682.

Dellino, P., Mele, D., Sulpizio, R., La Volpe, L., Braia, G., 2008. A method for the calculation of the impact parameters of dilute pyroclastic density currents based on deposit particle characteristics, J Geophys. Res. 113, B07206, 1-21.

Edbrooke S.W., Mazengarb C. and Stephenson W., 2003. Geology and geological hazards of the Auckland urban area, New Zealand. Quaternary International. 103:3-2. 
NOTICE: this is the author's version of a work that was accepted for publication in Journal of Volcanology and Geothermal Research. Changes resulting from the publishing process, such as peer review, editing, corrections, structural formatting, and other quality control mechanisms may not be reflected in this document. Changes may have been made to this work since it was submitted for publication. A definitive version was subsequently published in Journal of Volcanology and Geothermal Research, (2014). DOI: 10.1016/j.jvolgeores.2014.01.008

Fisher, R.V., Schmincke, H-U., 1984. Pyroclastic Rocks. Springer-Verlag, Berlin.

Freundt, A., Bursik, M.I., 1998. Pyroclastic Flow Transport Mechanisms; in From Magma to Tephra, Edited by A. Freundt and M. Rosi, pp. 25-51, Elsevier, Amsterdam.

Hazen A (1904) On sedimentation. Trans Am Soc Civ Engl 3: 45-88.

Hayward, J.J., Hayward, B.W., 1996. Fossil Forests Preserved in Volcanic Ash and Lava at Ihumatao and Takapuna, Auckland. Tane. 35:127-142.

Heiken, G.H., Wohletz, K., 1985. Volcanic ash. Univ. Calif. Press, Berkeley, CA, United States (USA).

Houghton, B.F., Wilson, C.J.N., Rosenberg, M.D., Smith, I.E.M., Parker, R.J., 1996. Mixed deposits of complex magmatic and phreatomagmatic volcanism: an example from Crater Hill, Auckland, New Zealand. Bull Volcanol 58:59-66.

Kereszturi, G., Németh, K., Cronin, S.J., Agustín-Flores, J., Smith, I.E.M., Lindsay, J. (submitted) A model for calculating eruptive volumes for monogenetic volcanoes - Implication for the Quaternary Auckland Volcanic Field, New Zealand J. Volcanol. Geotherm. Res. 266:1633.

Kermode, L.O., 1992. Geology of the Auckland urban area. Scale 1:50 000. Institute of Geological and Nuclear Sciences geological map 2. 1 sheet +63p. GNS Science, Lower Hutt

Le Corvec, N., Bebbington, M. S., Lindsay, J. M., \& McGee, L. E. (2013a). Age, distance and geochemical evolution within a monogenetic volcanic field: Analyzing patterns in the Auckland volcanic field eruption sequence. Geochemistry, Geophysics, Geosystems, n/a.

doi:10.1002/ggge.20223

Le Corvec, N., K. B. Spörli, J. Rowland, and J. Lindsay (2013b), Spatial distribution and alignments of volcanic centers: Clues to the formation of monogenetic volcanic fields, Earth Sci. Rev., 124, 96-114.

Lindsay, J., Marzocchi, W., Jolly G., Constantinescu, R., Selva, J., Sandri, L., 2010. Towards real-time eruption forecasting in the Auckland Volcanic Field: application of BET_EF during the New Zealand National Disaster Exercise Ru-aumoko. Bull Volcanol 72:185-204.

Magill CR, McAneney KJ, Smith IEM (2005) Probabilistic assessment of vent locations for the next Auckland volcanic field event. Math Geol 37:227-242

Marra, M.J., Alloway, B.V., Newnham, R.M., 2006. Paleoenvironmental reconstruction of a well-preserved Stage 7 forest sequence catastrophically buried by basaltic eruptive deposits, northern New Zealand. Quat. Sci. Rev. 25:2143-2161.

Mastin, L.G., Witter, J.B., 2000. The hazards of eruptions through lakes and seawater. J. Volcanol. Geotherm. Res. 97:195-214. 
Moore, J.G., 1967. Base surge in recent volcanic eruptions, Bull. Volcanol. 30, 337-363.

Morrissey, M., Zimanowski, B., Wohletz, K., Buettner, R., 2000. Phreatomagmatic fragmentation. In: H. Sigurdsson, B. Houghton, S.R., McNutt, H., Rymer, and J. Stix (Editors), Encyclopedia of Volcanoes. Academic Press, London, 431-445.

Nemeth, K., Cronin, S.J., 2007. Syn- and post-eruptive erosion, gully formation, and morphological evolution of a tephra ring in tropical climate erupted in 1913 in West Ambrym, Vanuatu. Geomorphology. 86:115-130.

Nemeth, K., Cronin, S.J., Charley, D., Harrison, M., and Garae E., 2006. Exploding lakes in Vanuatu; "Surtseyan-style" eruptions witnessed on Ambae Island. Episodes. 29, 87-92.

Panton, R.L., 1996. Incompressible Flow. Wiley, New York, 837 pp.

Parker, G., Fukushima, Y., and Yu, W., 1987. Experiments on turbidity currents over an erodible bed. J. Hydr. Res. 25: 123-147.

Rae, W.H., Pope, A., 1984. Low-Speed Wind Tunnel Testing. Wiley, New York, 534 pp

Rohrer, R., 1965. Base surge and cloud formation — project pre-Schooner. Calif. Univ., Livermore, Lawrence Radiation Lab., PNE-503F.

Sandri, L., Jolly, G., Lindsay, J., 2012. Combining long- and short-term probabilistic volcanic hazard assessment with cost-benefit analysis to support decision making in a volcanic crisis from the Auckland Volcanic Field, New Zealand. Bull Volcanol 74:705-723.

Schlichting, H., 1979. Boundary-layer theory. McGraw-Hill Book Co, New York.

Searle, E.J., 1964. City of volcanoes. A geology of Auckland. Longman Paul, Auckland, 112p

Shane P, Sandiford A (2003) Paleovegetation of marine isotope stages 4 and 3 in northern New Zealand and the age of the widespread Rotoehu Tephra. Quat Res 59:420-429

Smith, I.E.M., Allen, S.R., 1993. Volcanic Hazards at the Auckland Volcanic Field. Auckland Volcanic Field. Ministry of Civil Defense, Volcanic Hazards Information Booklet No. 5, 34p.

Sohn, Y.K., Chough, S.K., 1989. Depositional processes of the Suwolbong tuff ring, Cheju Island (Korea). Sediment. 36, 837-855.

Sparks, R.S.J., Wilson, L., Hulme, G., 1978. Theoretical modeling of the generation, movement, and emplacement of pyroclastic flows by column collapse. Journal of Geophysical Research 83: 1727-1739. 
Takahashi, T., 2001. Mechanics and simulation of snow avalanches, pyroclastic flows and debris flows. In: Particulate Gravity Currents (Eds W.D. McCaffrey, B.D. Kneller, J.J. Peakall) Spec. Publs. Int. Assoc. Sediment, No. 31, Blackwell Science, Oxford.

Valentine, G.A., 1987. Stratified flow in pyroclastic surges. Bull. Volcanol. 49, 616-630.

Wohletz, K.H., Sheridan, M.F., 1979. Model of Pyroclastic Surge. Geol. Soc. Am. Paper 180, 177-194.

Wohletz, K.H., 1998. Pyroclastic Surges and Compressible Two-Phase Flow; in From Magma to Tephra, Edited by A. Freundt and M. Rosi, pp. 25-51, Elsevier, Amsterdam.

Wohletz, K.H., McQueen, R.G., 1984. Experimental Studies of Hydromagmatic Volcanism. Studies of Geophysics. Natl. Acad. Press., Washington, DC pp 158-169.

Woods, A.W., and Bursik, M.I., 1994. A laboratory study of ash flows. J. Geophys. Res. 99: 4375-4394. 


\section{Figure Captions:}

Figure 1: (a) Location of Maungataketake tuff ring in the North Island of, New Zealand; (b) Digital elevation model of the Manukau harbor and surrounds (c) Digital elevation model (DEM) of the Maungataketake tuff ring. The tuff ring is $\sim 1 \mathrm{~km}$ by $0.75 \mathrm{~km}$.

Figure 2: Early aerial photograph of the Maungataketake tuff ring-scoria cone complex before quarrying operations began in the early $20^{\text {th }}$ century. The scoria cone in the photo is $80 \mathrm{~m}$ tall and was reshaped (terraced) by early Maori settlers.

Figure 3: DEM of Maungataketake tuff ring rim showing the outline of the maar structure, approximate initial vent location, stratigraphic section locations (S1-S6) and rose diagrams complied from the distribution and orientation of trees within the lower phreatomagmatic sequence (more data on trees available in supplementary Table 3). The coastline is represented by the abrupt transition to blue, with the lighter blue area representing the intertidal zone.

Figure 4: (a) General stratigraphic section illustrating bedding features and breakdown of depositional packages (NV, PH1, PH2, PH3 and M1) and lithofacies (see Table 1 and supplementary Tables 1 and 2 for lithofacies descriptions); (b-d) photographs of the PH1 sequence including entrained trees stumps and branches; (e) PH2 sequence; (f) PH3 sequence; (g) disconformable contact of PH3 and M1.

Figure 5: (a-d) Surface view exposures of dipping bedforms and large ballistics at S1. Ruler is $20 \mathrm{~cm}$ for scale in b-c; person $1.8 \mathrm{~m}$ tall for scale in a and d; (e) stratigraphic section for S2; (f-g) lithofacies LT1/TB1 exposed at the base of PH1 (20 cm ruler for scale); (h) juvenile ballistic (20 cm ruler for scale); (i) T1/T2 overlying LT1/TB1 (40 cm ruler for scale).

Figure 6: (a) Stratigraphic column for section PH1 of S3; (b-d) Basal contact between organicrich substrate and PH1; (e) ballistic bedding plane sag in PH11 (f) In place tree encapsulated by PH1 deposits at location S4 (tree $2 \mathrm{~m}$ tall) (g) stratigraphic column for PH1 of section S4

Figure 7: (a) Stratigraphic column for section PH1 of S4; (b) Photograph of PH1 with in place trees stump protruding from the deposits (meter stick for scale); (c-d) Photographs of outcrop with tree molds remnants (white ruler on outcrop in $c$ is $20 \mathrm{~cm}$ in length).

Figure 8: Photographs from S6. (a) Shallow-dipping meter-scale wavy to cross-stratified deposits from PH1 and the lower-most section of PH2; (b) Cast of a large tree encapsulated but left standing from the PH1 and PH2 base surges. Meter stick extended to $1.2 \mathrm{~m}$ for scale in both (a) and (b). Flow direction was from left to right. Note the steep dipping beds on the upstream side of the tree, which transition to down-dipping beds on the downstream side. The tree cast has a slight tilt toward the downstream flow direction; (c, e) tree casts within PH1 deposits. Ruler 20 $\mathrm{cm}$ for scale. (d) smaller tree casts within the intertidal zone (meter stick for scale); (f) accretionary lapilli in lithofacies T2 strata; (g) tiny root casts in intertidal area (ruler $20 \mathrm{~cm}$ for scale); (h) preserved plaster $2-3 \mathrm{~cm}$ thick which once surrounded a small standing tree. Tree cast $0.4 \mathrm{~m}$ tall. 
Figure 9: Best fit numerical modeling results for Temperatures of 741 and $822 \mathrm{~K}$. Parameters listed in Table 3. Black line in dynamic pressure vs. distance plot represents the lowest critical value of $\mathrm{P}_{\mathrm{dyn}}$ to snap the trees.

Figure 10: Numerical modeling results varying initial bulk density $(\beta)$

Figure 11: Numerical modeling results varying initial bulk density $(h)$

Figure 12: Numerical modeling results varying initial initial velocity $(u)$

Figure 13: Numerical modeling results for an average case scenario (see Table 4 for initial conditions). Run represented by the blue line has similar conditions as Maungataketake but slightly higher initial bulk density. Run represented by the red line has slightly higher initial bulk density, same collapse height but thicker initial current. Run represented by the green line has the same bulk density as the blue and red runs but has higher column collapse height, higher initial velocities and initially thicker current.

Figure 14: Numerical modeling results for a "worst case scenario" with initial bulk densities of $60 \mathrm{~kg} \mathrm{~m}^{-3}$ and initial velocities ranging from $80-140 \mathrm{~m} \mathrm{~s}^{-1}$ (see Table 5 for initial conditions).

\section{Table Captions:}

Table 1: Lithofacies designations

Table 2: Table listing (1) each section location with respect to distance from source, (2) Thickness of FA at each location (NE - Not exposed; BNE = base not exposed; TNE = Top not exposed; N/A = not present), and (3) size of ballistics found in each location for each facies association $(\mathrm{J}=$ juvenile; $\mathrm{A}=$ accidental; N/A = no ballistics found; ballistics measured along two longest axes). For locations with $>5$ ballistics, only the five largest are listed.

Table 3: List of symbols and range of initial parameters

Table 4: Parameters for "average" case scenarios, with runout distances of $\sim 3-4 \mathrm{~km}$, and "worst" case scenarios, with runout distances of $\sim 4-6 \mathrm{~km}$. Numbers bolded in Table 3 are used here unless otherwise specified in the table.

\section{Supplementary Figure Captions:}

Supplementary Figure 1: The modeled velocity evolution and runout distance (red line, using the above input parameters) are compared against data for the Sedan weapons test (green circles, data from Moore 1967). The final runout distance of the base surges associated with the Sedan test was $3 \mathrm{~km}$. 
Supplementary Figure 2: The modeled sedimentation rate (lines), using the above input parameters (red line uses set 1; blue lines uses set 2) are compared against deposit thickness data for the 1965 Taal eruption (red circles, Moore 1967) and the 1996 eruption in Karymskoye lake (blue circles, Belousov and Belousova 2001). The model input parameters were approximated by considering observations of the two events and their deposits (initial velocities, representative grain size, initial base surge radius, substrate slope), and when observations proved insufficient, the reference case values were used (initial current density, friction factor). Although we do not directly calculate the modeled deposit thickness, we assume that sedimentation rate is a reasonable proxy for deposit distribution.

Supplementary Figure 3: Numerical modeling results varying initial grain size (Dp). Other initial conditions same as 'best fit' in Figure 9.

Supplementary Figure 4: Numerical modeling results varying initial slope. Other initial conditions same as 'best fit' in Figure 9.

Supplementary Figure 5: Numerical modeling results varying friction coefficient $(f)$. Other initial conditions same as 'best fit' in Figure 9.

\section{Supplementary Table Captions:}

Supplementary Table 1: Accidental lithic abbreviations

\section{Supplementary Table 2: Lithofacies Descriptions and Interpretations}

Supplementary Table 3: Location and orientation of tree trunks and limbs found within the PH1 deposits. Flow orientation from the casts was measured based on the axis of deformation where the strata are bent upwards around the tree (see text for more details). 
Table 1: Lithofacies designations (full description available as online supplemental material)

\begin{tabular}{|l|c|c|c|c|c|}
\hline Lithofacies & $\begin{array}{c}\text { Tuff } \\
\text { Breccia } \\
\text { (TB) }\end{array}$ & $\begin{array}{c}\text { Lapilli Tuff } \\
\text { (LT) }\end{array}$ & $\begin{array}{c}\text { Tuff } \\
\text { (T) }\end{array}$ & $\begin{array}{c}\text { Magmatic } \\
\text { (M) }\end{array}$ & $\begin{array}{c}\text { Non- } \\
\text { Volcanic } \\
\text { (NV) }\end{array}$ \\
\hline $\begin{array}{l}\text { Pre-Maungataketake } \\
\text { Eruption }\end{array}$ & & & & NV \\
\hline Maungataketake Eruptive Deposits & & & & \\
\hline Clast Supported & TB1 & LT1 & & LT4 & \\
\hline Massive & & T8 & \\
\hline Stratified & LT2 & T4 & & \\
\hline $\begin{array}{l}\text { Massive-to-diffuse } \\
\text { stratification, reverse grading, } \\
80-95 \% \text { clast supported }\end{array}$ & & & & & \\
\hline $\begin{array}{l}\text { Stratified, reverse grading, } \\
>95 \% \text { clast supported }\end{array}$ & & LT3 & T5 & & \\
\hline Matrix Supported & & & T1 & & \\
\hline Massive to faintly laminated & & & T2 & & \\
\hline Stratified, laminated & & & $T 3, T 6, T 7$ & & \\
\hline Cross stratified-laminated & & &
\end{tabular}


NOTICE: this is the author's version of a work that was accepted for publication in Journal of Volcanology and Geothermal Research. Changes resulting from the publishing process, such as peer review, editing, corrections, structural formatting, and other quality control mechanisms may not be reflected in this document. Changes may have been made to this work since it was submitted for publication. A definitive version was subsequently published in Journal of Volcanology and Geothermal Research, (2014). DOI: 10.1016/j.jvolgeores.2014.01.008

Table 2: Table listing (1) each section location with respect to distance from source, (2) Thickness of FA at each location (NE - Not exposed; BNE = base not exposed; TNE = Top not exposed; N/A = no ballistics found), and (3) size of ballistics found in each location for each facies association ( $\mathrm{J}=$ juvenile; $\mathrm{A}=$ accidental; measured along two longest axes). For locations with $>5$ ballistics, only the five largest are listed.

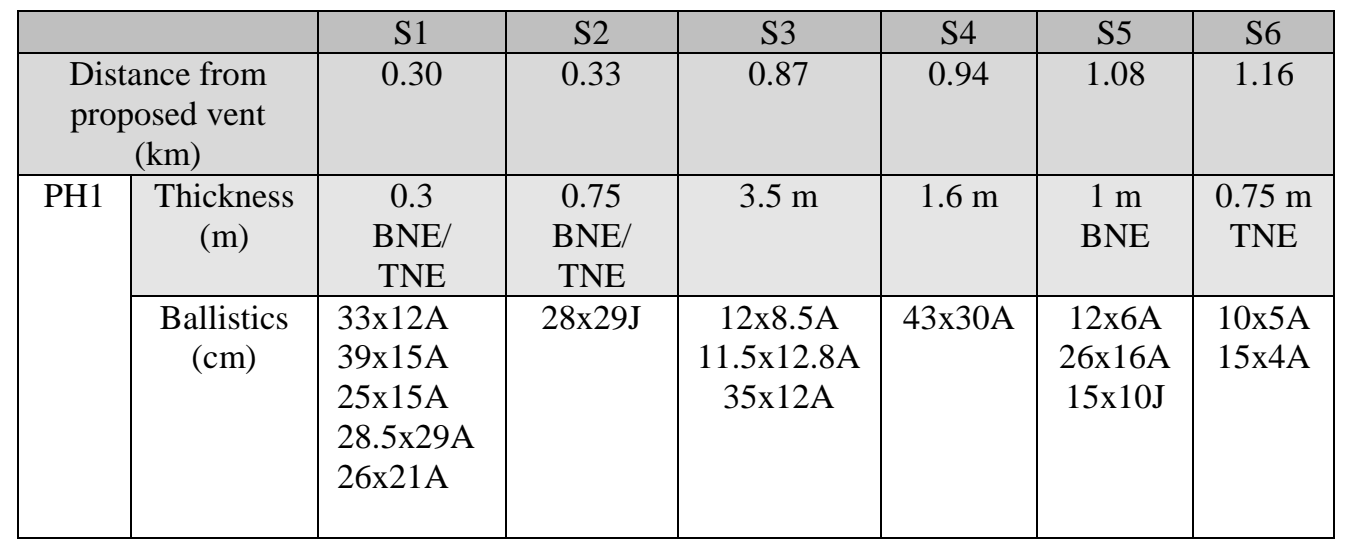


Table 3: List of symbols and range of initial parameters

\begin{tabular}{|c|c|}
\hline \multicolumn{2}{|c|}{ Constants } \\
\hline $\mathrm{C}_{\mathrm{D}}$ & $\begin{array}{l}1.1 \text { (for } 10<\operatorname{Re}<\sim 4 \times 10^{5} ; \text { i.e., } \\
\text { Clarke and Voight, } 2000 \text { ) }\end{array}$ \\
\hline$c_{a}$ & $1005 \mathrm{~J} \mathrm{~kg}^{-1} \mathrm{~K}$ \\
\hline $\mathrm{c}_{\text {watervapor }}$ & $2425 \mathrm{~J} \mathrm{~kg}^{-1} \mathrm{~K}$ \\
\hline $\mathrm{g}$ & $9.81 \mathrm{~m} \mathrm{~s}^{-2}$ \\
\hline $\mathrm{h}_{\text {tree }}$ & $5-9 \mathrm{~m}$ \\
\hline $\mathrm{n}_{\mathrm{m}}$ & 0.02 \\
\hline $\mathrm{p}$ & 1 e $5 \mathrm{~Pa}$ \\
\hline$r_{\text {tree }}$ & $0.15-.25 \mathrm{~m}$ \\
\hline $\mathrm{R}$ & $\begin{array}{l}462 \mathrm{~J} \mathrm{~kg}^{-1} \mathrm{~K} \text { (assuming } \\
\text { water vapor; Woods, 1988; } \\
\text { Bursik and Woods, 1996) }\end{array}$ \\
\hline$r_{0}$ & $200 \mathrm{~m}$ \\
\hline $\mathrm{T}_{\mathrm{a}}$ & $288 \mathrm{~K}$ \\
\hline$\alpha$ & $1.225 \mathrm{~kg} \mathrm{~m}^{-3}$ \\
\hline$\sigma_{\text {ult, yield }}$ & Podocarpus totara \\
\hline$\rho_{\mathrm{s}}$ & $2700 \mathrm{~kg} \mathrm{~m}^{-3}$ \\
\hline$\theta$ & 1 \\
\hline \multicolumn{2}{|c|}{$\begin{array}{l}\text { Parameters to vary (bold are best fit to Maungatketake } \\
\text { data) }\end{array}$} \\
\hline $\mathrm{T}_{\text {magma }}$ & 822 K; 373 - 1473 K \\
\hline $\mathrm{h}_{0}$ & $\mathbf{6 0} \mathbf{~ m} ; 30-100 \mathrm{~m}$ \\
\hline$f$ & $\mathbf{0 . 0 2} ; 0.001$ to 0.02 \\
\hline $\mathrm{u}_{0}$ & $65 \mathrm{~m} \mathrm{~s}^{-1} ; 50-200 \mathrm{~m} \mathrm{~s}^{-1}$ \\
\hline$\beta_{0}$ & $38 \mathbf{~ k g ~ m}^{-3} ; 20-70 \mathrm{~kg} \mathrm{~m}^{-3}$ \\
\hline$D_{P}$ & $\mathbf{0 . 5} \mathbf{~ m m} ; 0.01-1 \mathrm{~cm}$ \\
\hline$\theta$ & $1 ; 0-25$ degrees \\
\hline
\end{tabular}


Table 4: Parameters for "average" case scenarios, with runout distances of $\sim 3-4 \mathrm{~km}$, and "worst" case scenarios, with runout distances of $\sim 4-6 \mathrm{~km}$. Numbers bolded in Table 3 are used here unless otherwise specified in the table.

\begin{tabular}{|c|c|c|c|}
\hline \multicolumn{4}{|c|}{ "average" case scenario } \\
\hline & Black & Red & Blue \\
\hline $\mathbf{T}_{\text {magma }}$ & $822 \mathrm{~K}$ & $822 \mathrm{~K}$ & $822 \mathrm{~K}$ \\
\hline$\beta$ & $\begin{array}{l}40 \mathrm{~kg} \\
\mathrm{~m}^{-}\end{array}$ & $\begin{array}{l}40 \mathrm{~kg} \\
\mathrm{~m}^{-}\end{array}$ & $\begin{array}{l}40 \mathrm{~kg} \\
\mathrm{~m}^{-3}\end{array}$ \\
\hline $\mathbf{u}$ & $65 \mathrm{~m} \mathrm{~s}^{-1}$ & $70 \mathrm{~m} \mathrm{~s}^{-1}$ & $90 \mathrm{~m} \mathrm{~s}^{-1}$ \\
\hline $\mathbf{h}_{0}$ & $60 \mathrm{~m}$ & $100 \mathrm{~m}$ & $150 \mathrm{~m}$ \\
\hline \multicolumn{4}{|c|}{ “worst” case scenario } \\
\hline & Black & Red & Blue \\
\hline $\mathbf{T}_{\text {magma }}$ & $822 \mathrm{~K}$ & $822 \mathrm{~K}$ & $822 \mathrm{~K}$ \\
\hline$\beta$ & $\begin{array}{l}60 \mathrm{~kg} \\
\mathrm{~m}^{-}\end{array}$ & $\begin{array}{l}60 \mathrm{~kg} \\
\mathrm{~m}^{-}\end{array}$ & $\begin{array}{l}60 \mathrm{~kg} \\
\mathrm{~m}^{-3}\end{array}$ \\
\hline $\mathbf{u}$ & $\begin{array}{l}80 \mathrm{~m} \mathrm{~s}^{-} \\
\left.{ }^{1}\right)\end{array}$ & $\begin{array}{l}100 \mathrm{~m} \\
\mathrm{~s}^{-1}\end{array}$ & $\begin{array}{l}140 \mathrm{~m} \\
\mathrm{~s}^{-1}\end{array}$ \\
\hline $\mathbf{h}_{0}$ & $200 \mathrm{~m}$ & $200 \mathrm{~m}$ & $200 \mathrm{~m}$ \\
\hline
\end{tabular}


NOTICE: this is the author's version of a work that was accepted for publication in Journal of Volcanology and Geothermal Research. Changes resulting from the publishing process, such as peer review, editing, corrections, structural formatting, and other quality control mechanisms may not be reflected in this document. Changes may have been made to this work since it was submitted for publication. A definitive version was subsequently published in Journal of Volcanology and Geothermal Research, (2014). DOI: 10.1016/j.jvolgeores.2014.01.008
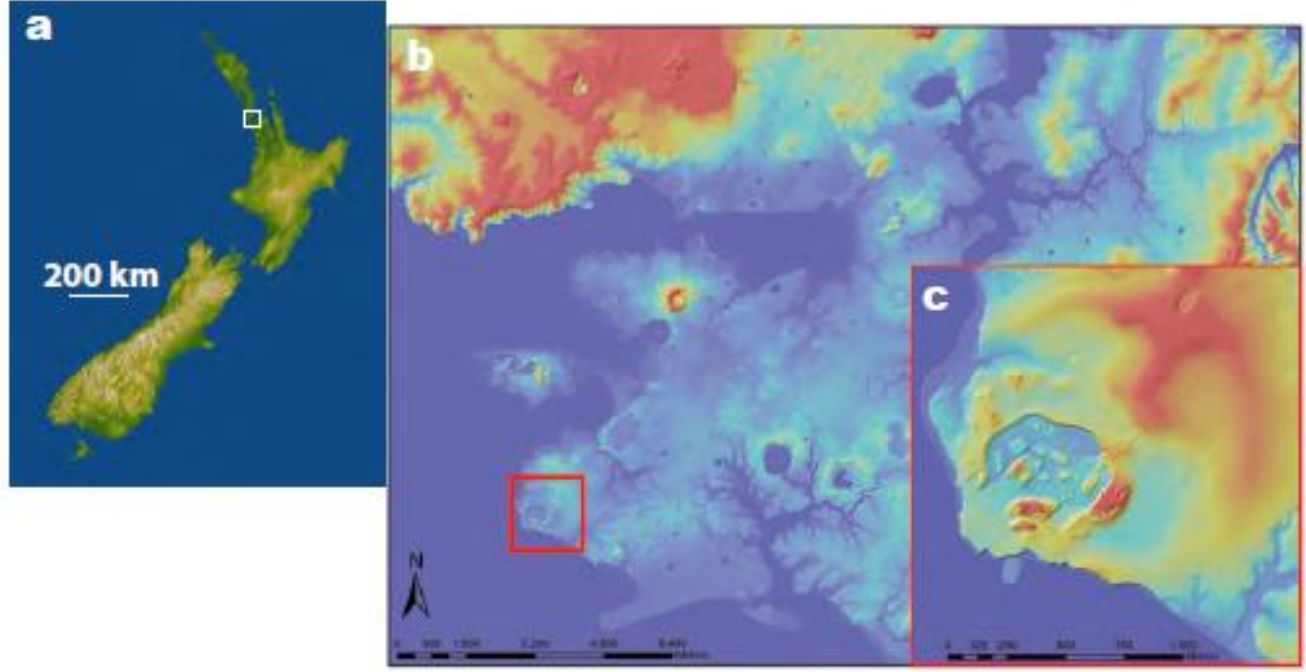

\section{Figure 1}


NOTICE: this is the author's version of a work that was accepted for publication in Journal of Volcanology and Geothermal Research. Changes resulting from the publishing process, such as peer review, editing, corrections, structural formatting, and other quality control mechanisms may not be reflected in this document. Changes may have been made to this work since it was submitted for publication. A definitive version was subsequently published in Journal of Volcanology and Geothermal Research, (2014). DOI: 10.1016/j.jvolgeores.2014.01.008

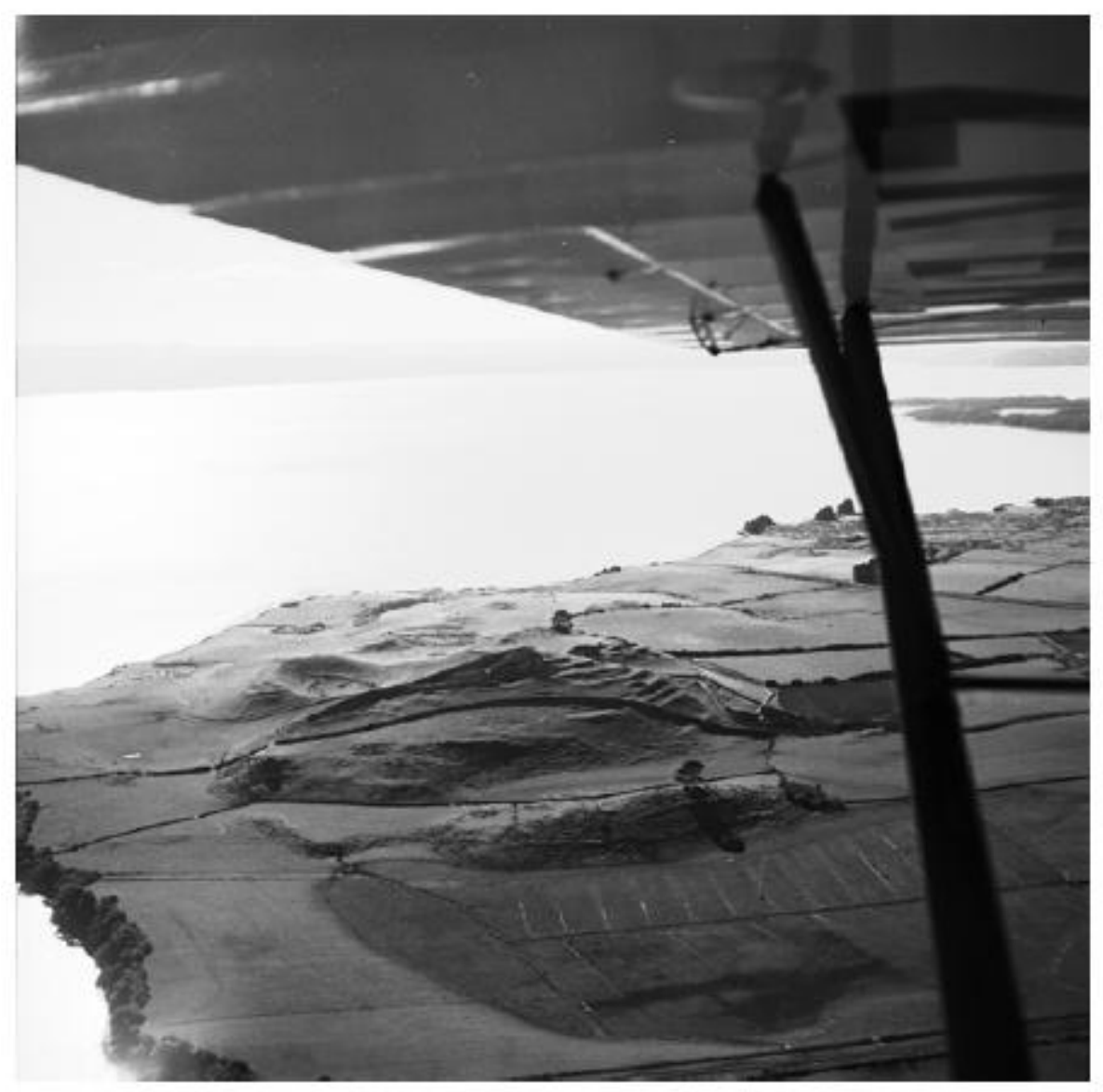

Figure 2 
NOTICE: this is the author's version of a work that was accepted for publication in Journal of Volcanology and Geothermal Research. Changes resulting from the publishing process, such as peer review, editing, corrections, structural formatting, and other quality control mechanisms may not be reflected in this document. Changes may have been made to this work since it was submitted for publication. A definitive version was subsequently published in Journal of Volcanology and Geothermal Research, (2014). DOI: 10.1016/j.jvolgeores.2014.01.008

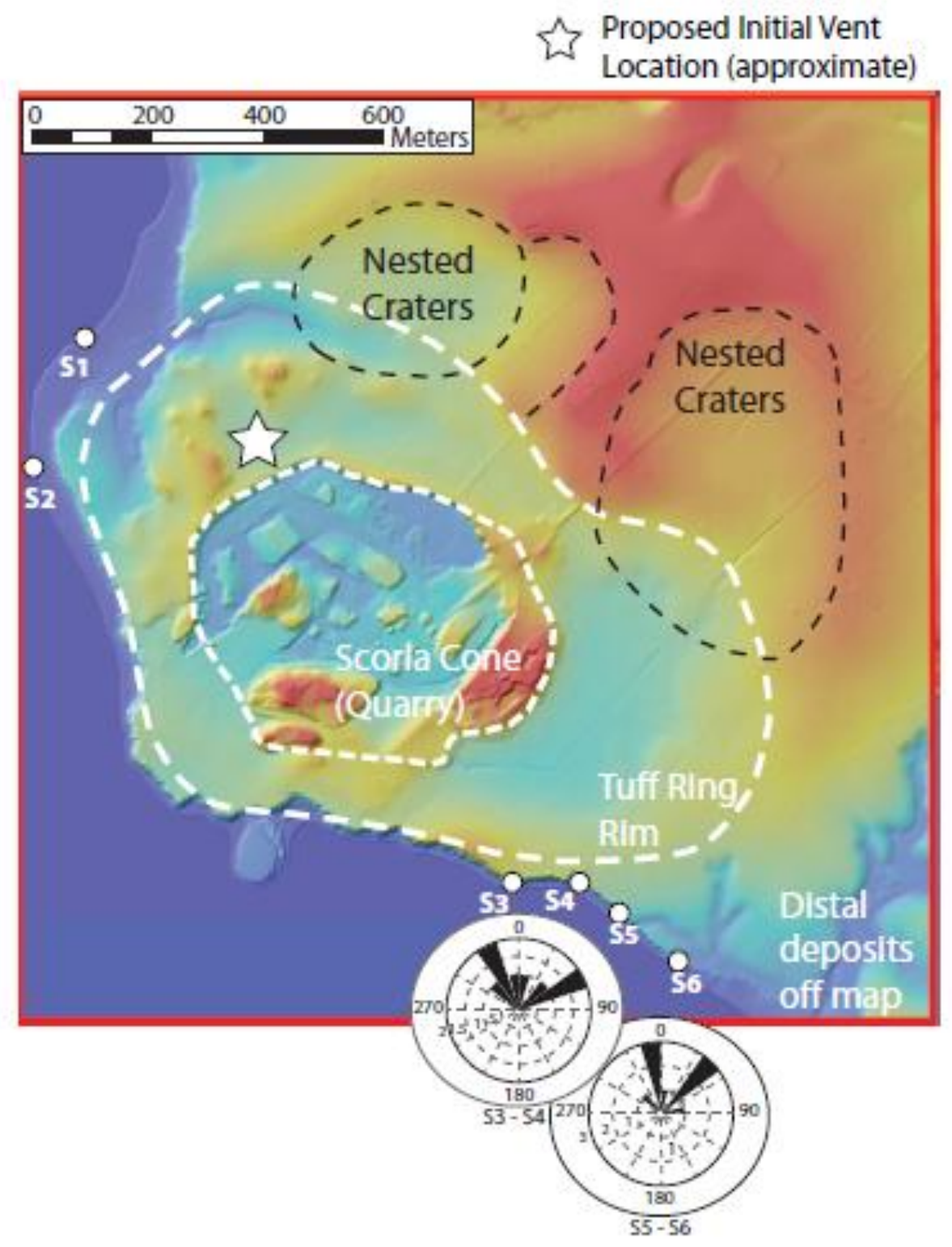

Figure 3 
NOTICE: this is the author's version of a work that was accepted for publication in Journal of Volcanology and Geothermal Research. Changes resulting from the publishing process, such as peer review, editing, corrections, structural formatting, and other quality control mechanisms may not be reflected in this document. Changes may have been made to this work since it was submitted for publication. A definitive version was subsequently published in Journal of Volcanology and Geothermal Research, (2014). DOI: 10.1016/j.jvolgeores.2014.01.008

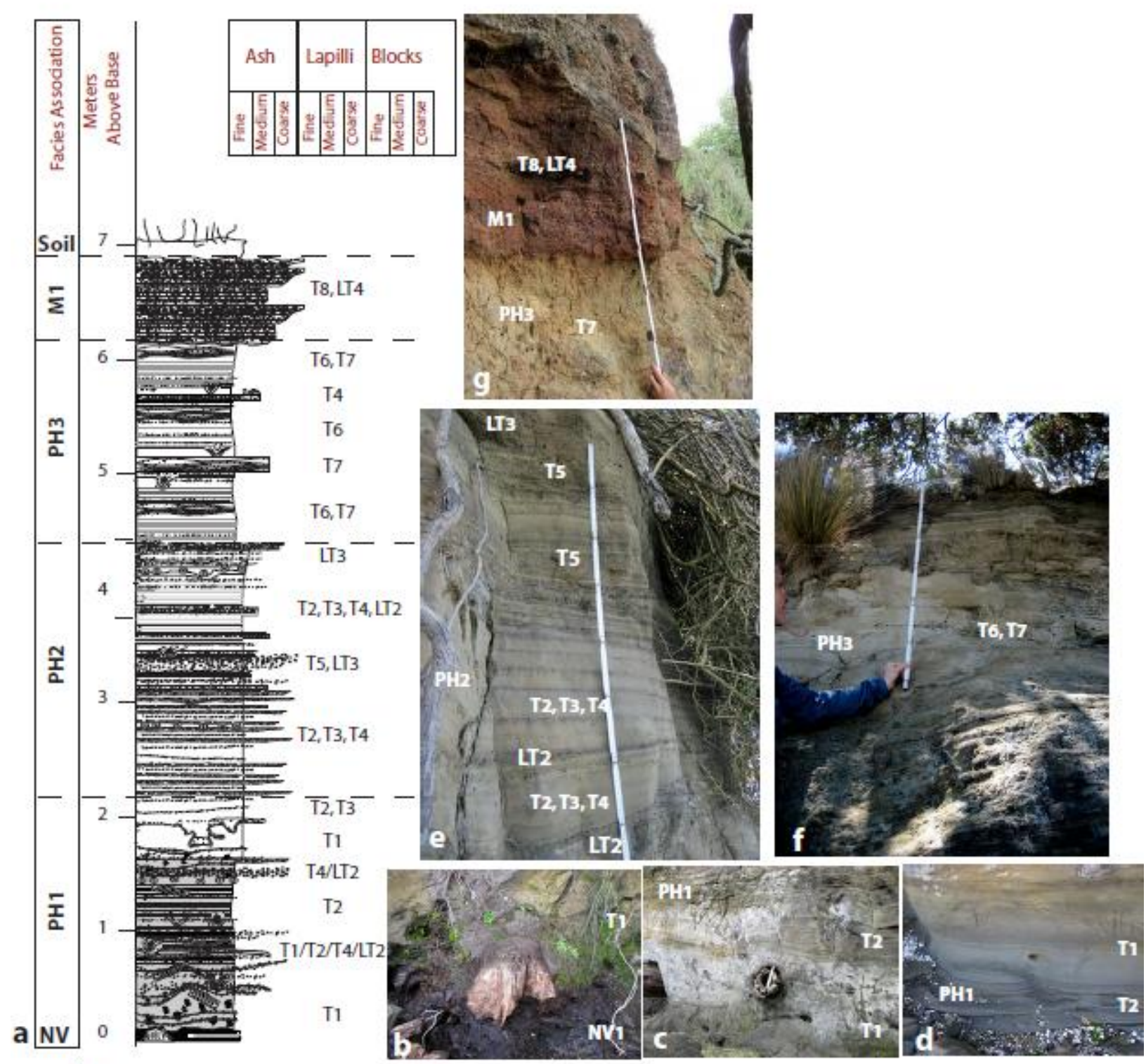

Key:

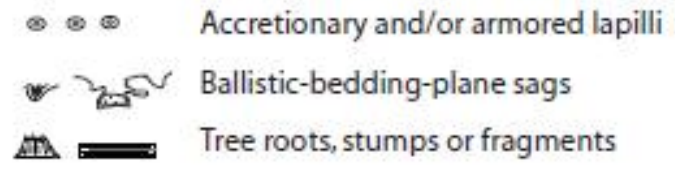

- 6 Accretionary and/or armored lapilli

* B Ballistic-bedding-plane sag

Tree roots, stumps or fragments

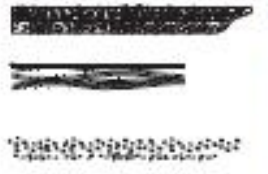

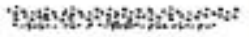

Clast-supported scoria beds

Cross-stratification

Nearly clast-supported beds with fine-grained matrix

Figure 4 
NOTICE: this is the author's version of a work that was accepted for publication in Journal of Volcanology and Geothermal Research. Changes resulting from the publishing process, such as peer review, editing, corrections, structural formatting, and other quality control mechanisms may not be reflected in this document. Changes may have been made to this work since it was submitted for publication. A definitive version was subsequently published in Journal of Volcanology and Geothermal Research, (2014). DOI: 10.1016/j.jvolgeores.2014.01.008
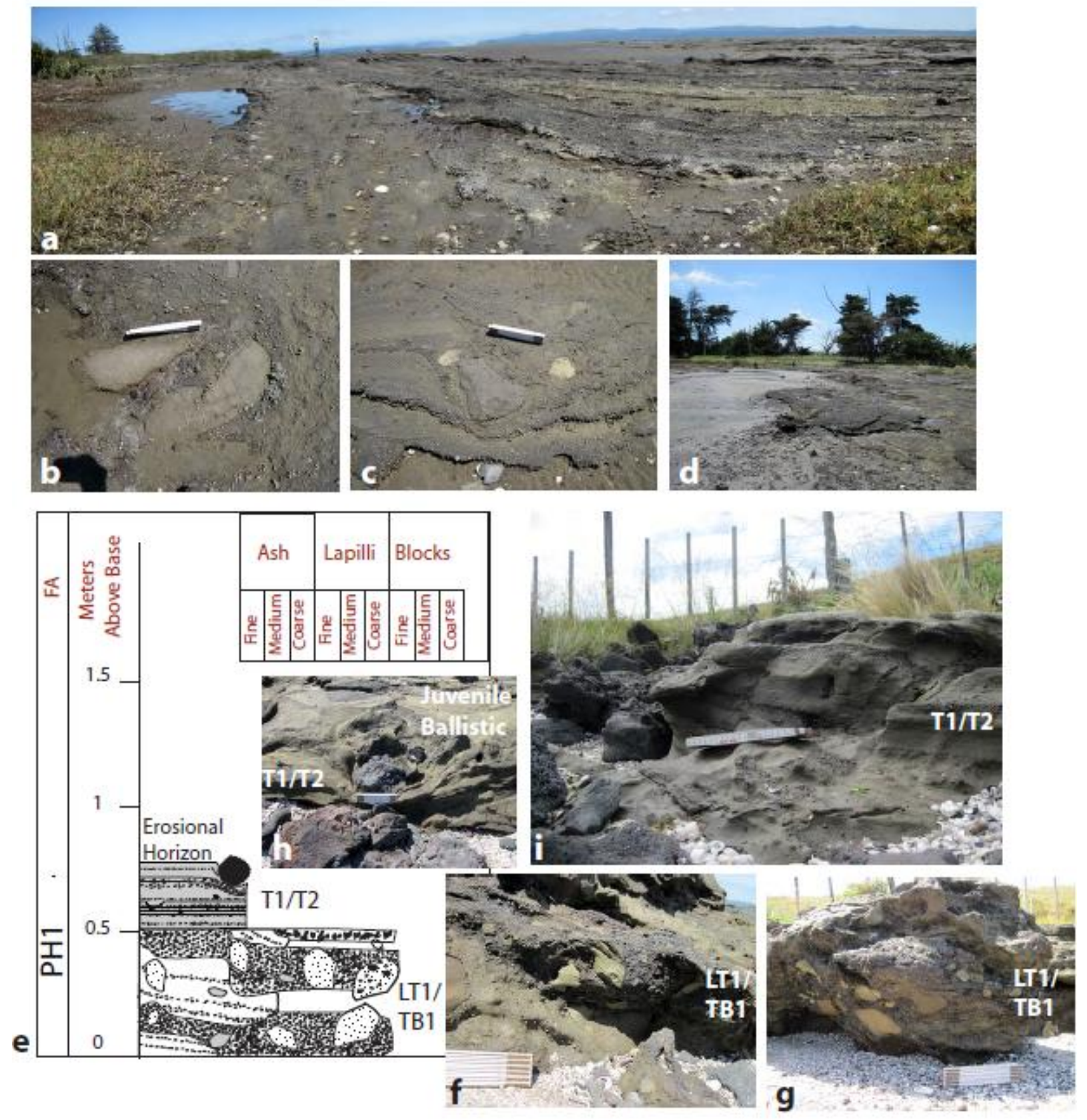

Figure 5 
NOTICE: this is the author's version of a work that was accepted for publication in Journal of Volcanology and Geothermal Research. Changes resulting from the publishing process, such as peer review, editing, corrections, structural formatting, and other quality control mechanisms may not be reflected in this document. Changes may have been made to this work since it was submitted for publication. A definitive version was subsequently published in Journal of Volcanology and Geothermal Research, (2014). DOI: 10.1016/j.jvolgeores.2014.01.008
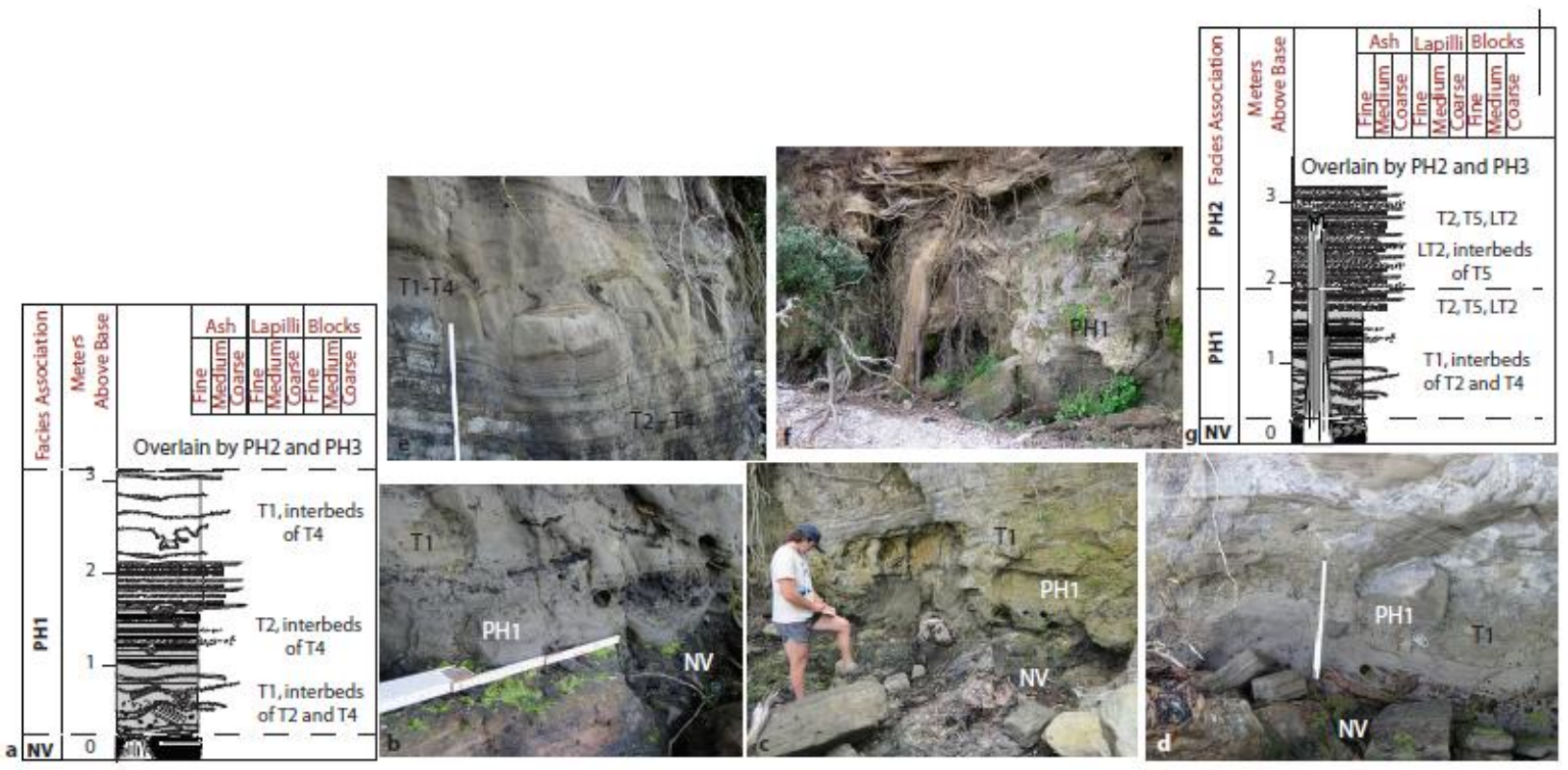

Figure 6 
NOTICE: this is the author's version of a work that was accepted for publication in Journal of Volcanology and Geothermal Research. Changes resulting from the publishing process, such as peer review, editing, corrections, structural formatting, and other quality control mechanisms may not be reflected in this document. Changes may have been made to this work since it was submitted for publication. A definitive version was subsequently published in Journal of Volcanology and Geothermal Research, (2014). DOI: 10.1016/j.jvolgeores.2014.01.008

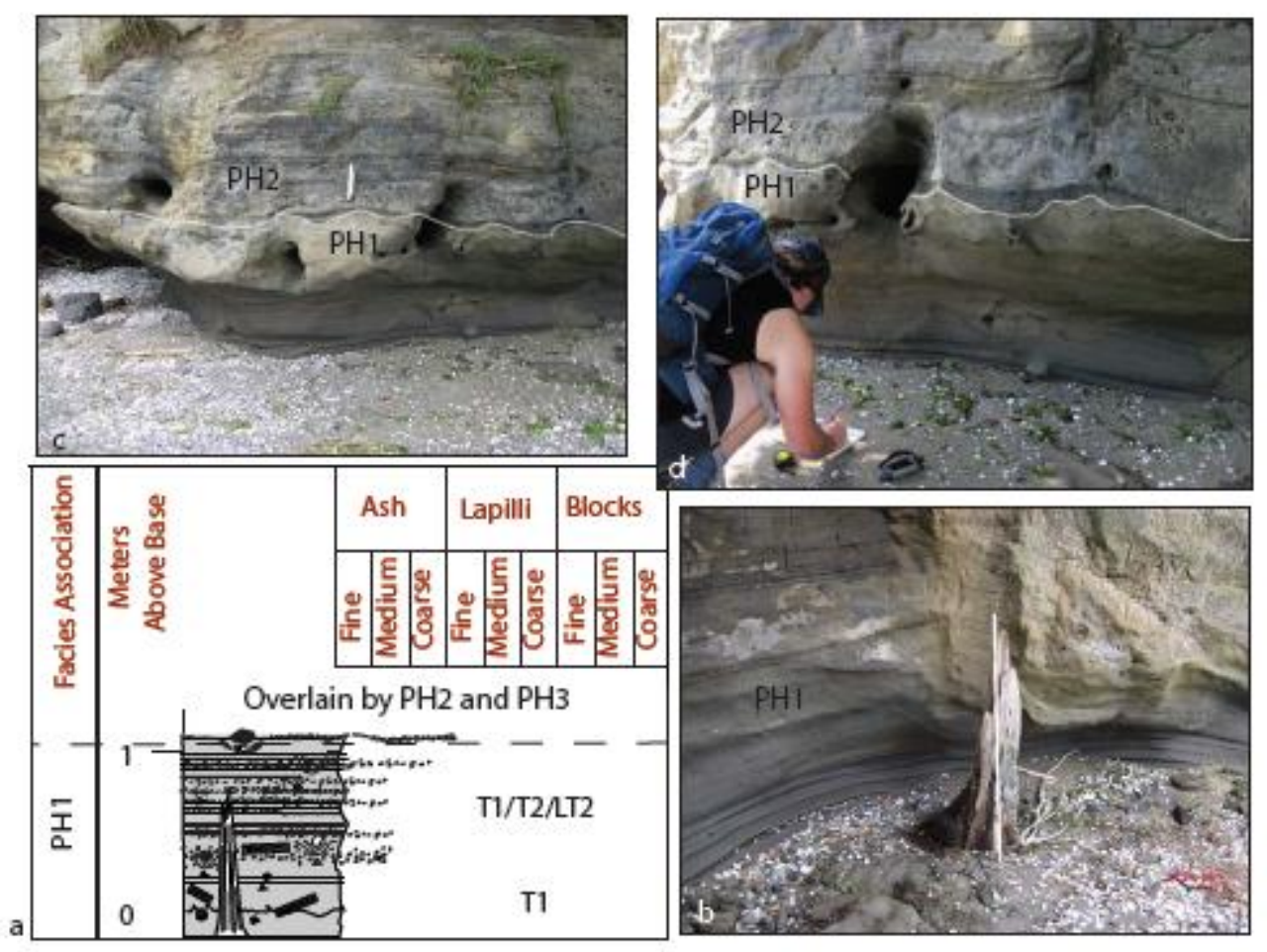

Figure 7 
NOTICE: this is the author's version of a work that was accepted for publication in Journal of Volcanology and Geothermal Research. Changes resulting from the publishing process, such as peer review, editing, corrections, structural formatting, and other quality control mechanisms may not be reflected in this document. Changes may have been made to this work since it was submitted for publication. A definitive version was subsequently published in Journal of Volcanology and Geothermal Research, (2014). DOI: 10.1016/j.jvolgeores.2014.01.008

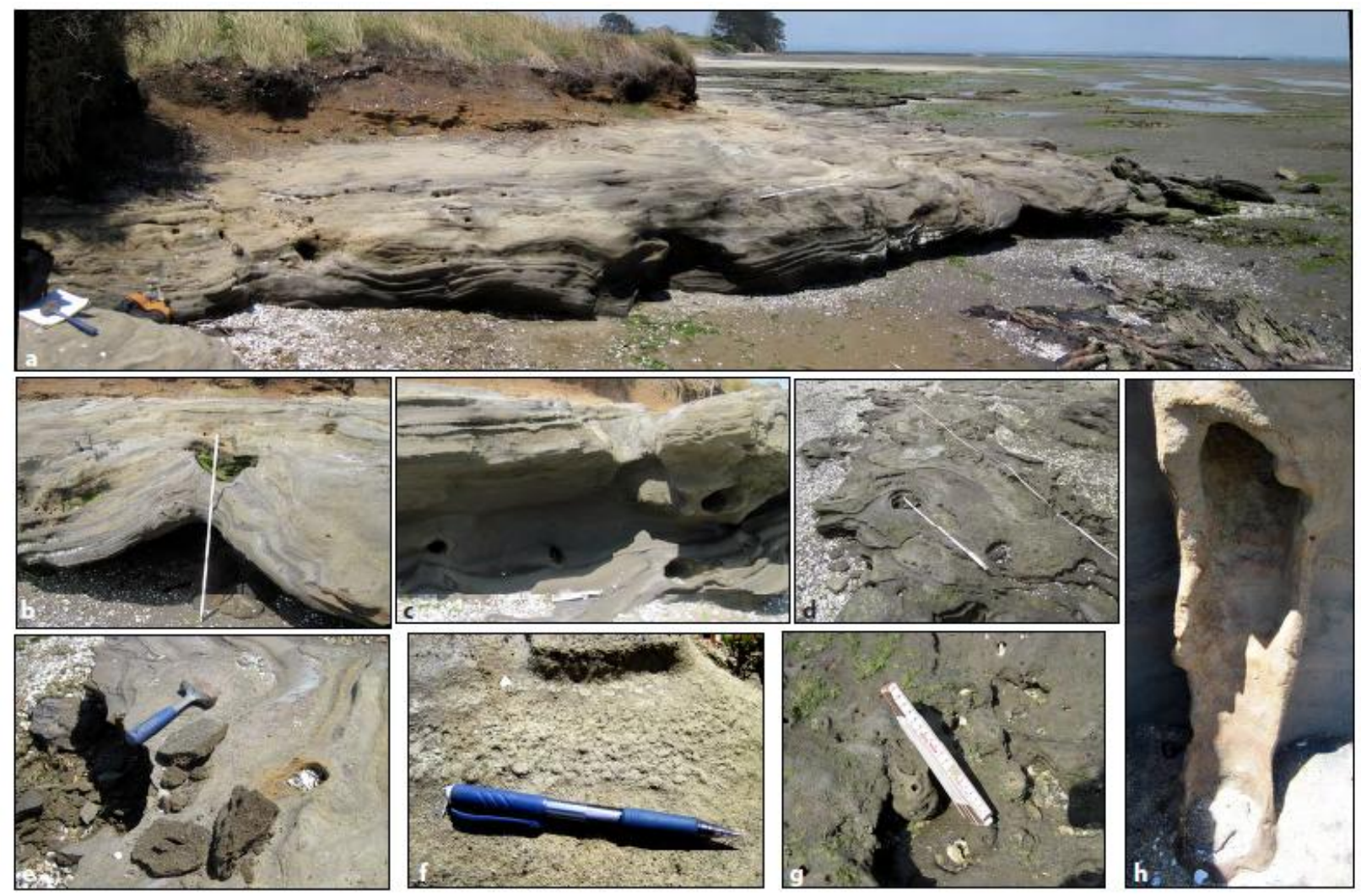

Figure 8 
NOTICE: this is the author's version of a work that was accepted for publication in Journal of Volcanology and Geothermal Research. Changes resulting from the publishing process, such as peer review, editing, corrections, structural formatting, and other quality control mechanisms may not be reflected in this document. Changes may have been made to this work since it was submitted for publication. A definitive version was subsequently published in Journal of Volcanology and Geothermal Research, (2014). DOI: 10.1016/j.jvolgeores.2014.01.008
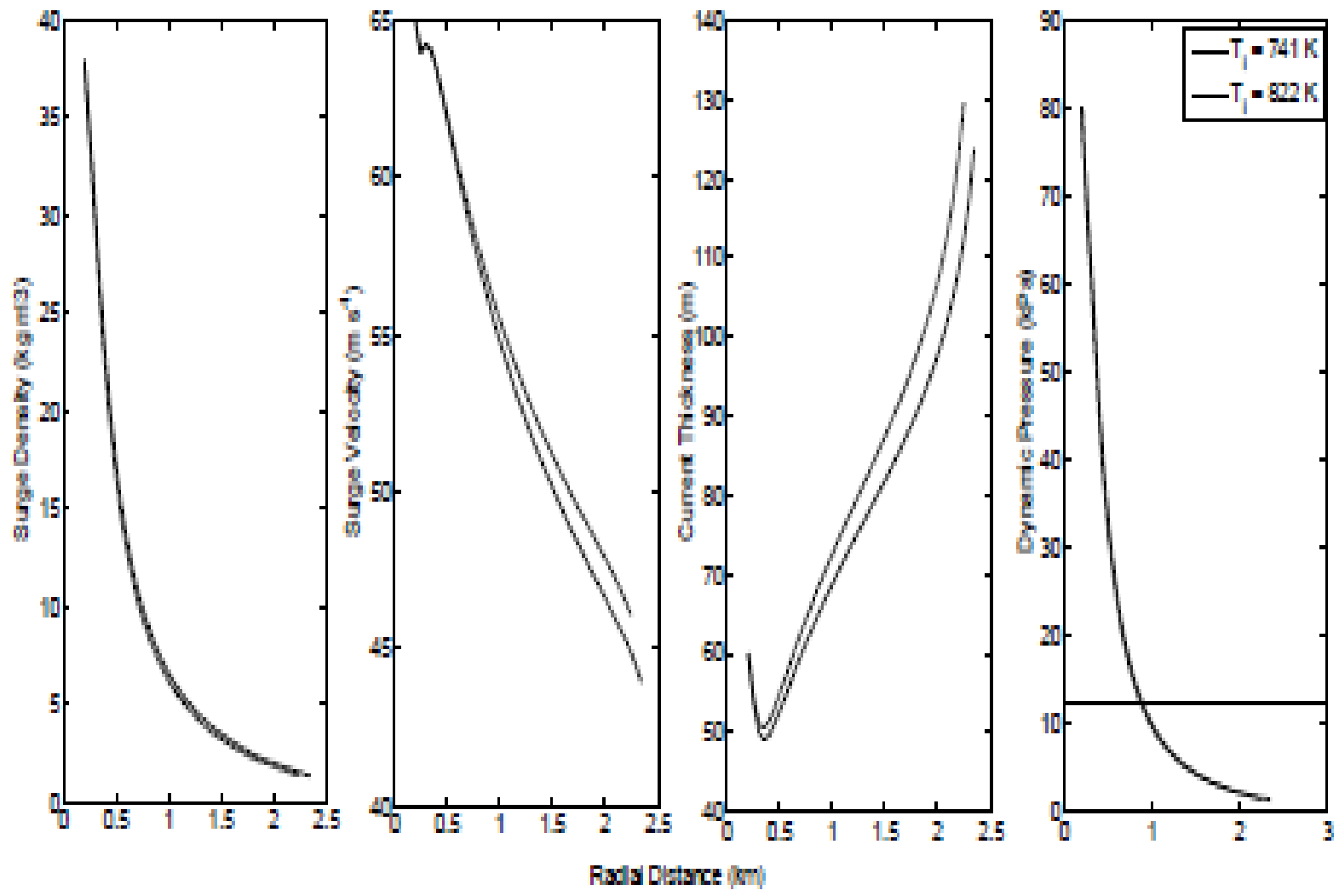

Figure 9 
NOTICE: this is the author's version of a work that was accepted for publication in Journal of Volcanology and Geothermal Research. Changes resulting from the publishing process, such as peer review, editing, corrections, structural formatting, and other quality control mechanisms may not be reflected in this document. Changes may have been made to this work since it was submitted for publication. A definitive version was subsequently published in Journal of Volcanology and Geothermal Research, (2014). DOI: 10.1016/j.jvolgeores.2014.01.008
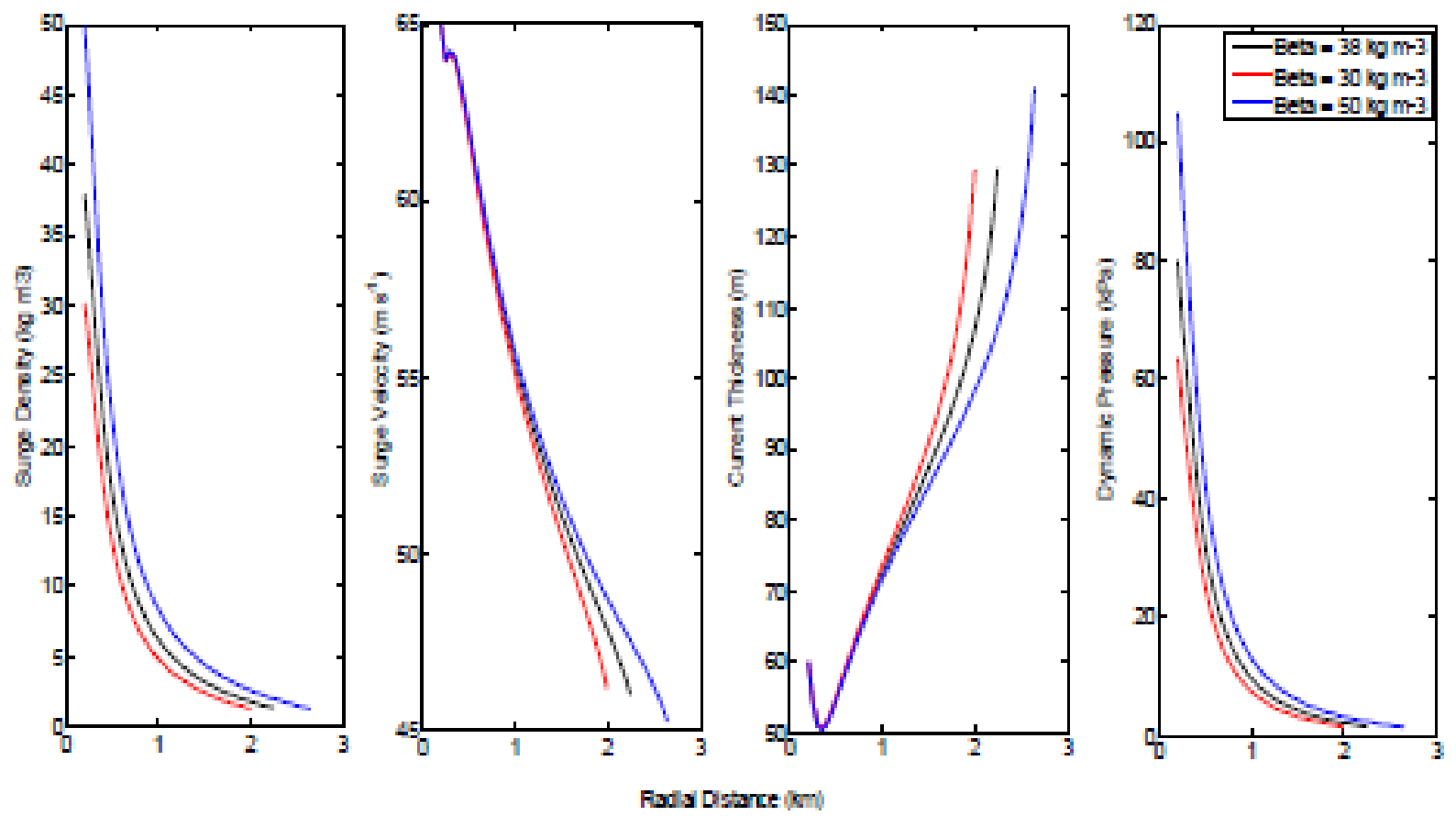

Figure 10 
NOTICE: this is the author's version of a work that was accepted for publication in Journal of Volcanology and Geothermal Research. Changes resulting from the publishing process, such as peer review, editing, corrections, structural formatting, and other quality control mechanisms may not be reflected in this document. Changes may have been made to this work since it was submitted for publication. A definitive version was subsequently published in Journal of Volcanology and Geothermal Research, (2014). DOI: 10.1016/j.jvolgeores.2014.01.008
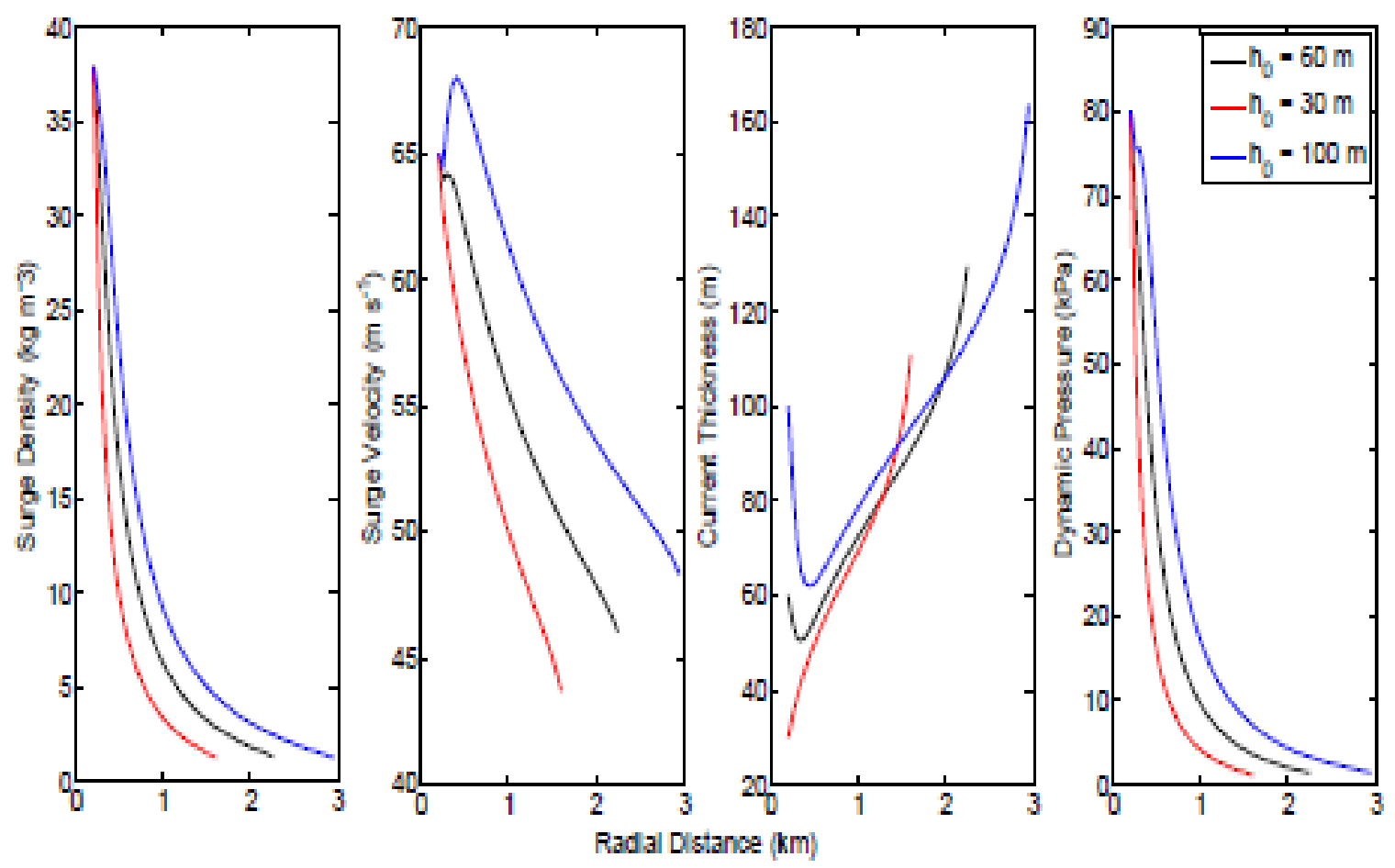

Figure 11 
NOTICE: this is the author's version of a work that was accepted for publication in Journal of Volcanology and Geothermal Research. Changes resulting from the publishing process, such as peer review, editing, corrections, structural formatting, and other quality control mechanisms may not be reflected in this document. Changes may have been made to this work since it was submitted for publication. A definitive version was subsequently published in Journal of Volcanology and Geothermal Research, (2014). DOI: 10.1016/j.jvolgeores.2014.01.008
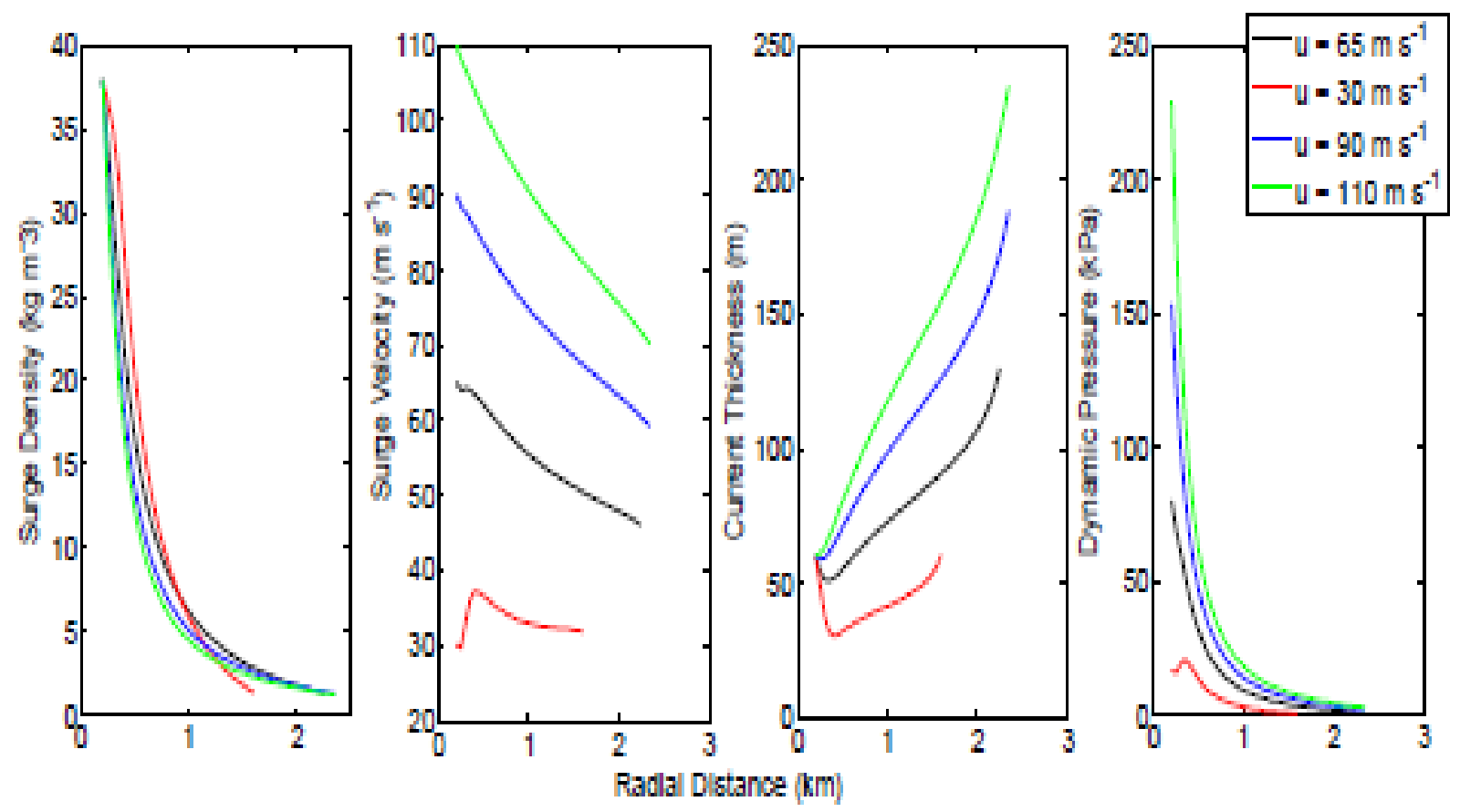

Figure 12 
NOTICE: this is the author's version of a work that was accepted for publication in Journal of Volcanology and Geothermal Research. Changes resulting from the publishing process, such as peer review, editing, corrections, structural formatting, and other quality control mechanisms may not be reflected in this document. Changes may have been made to this work since it was submitted for publication. A definitive version was subsequently published in Journal of Volcanology and Geothermal Research, (2014). DOI: 10.1016/j.jvolgeores.2014.01.008
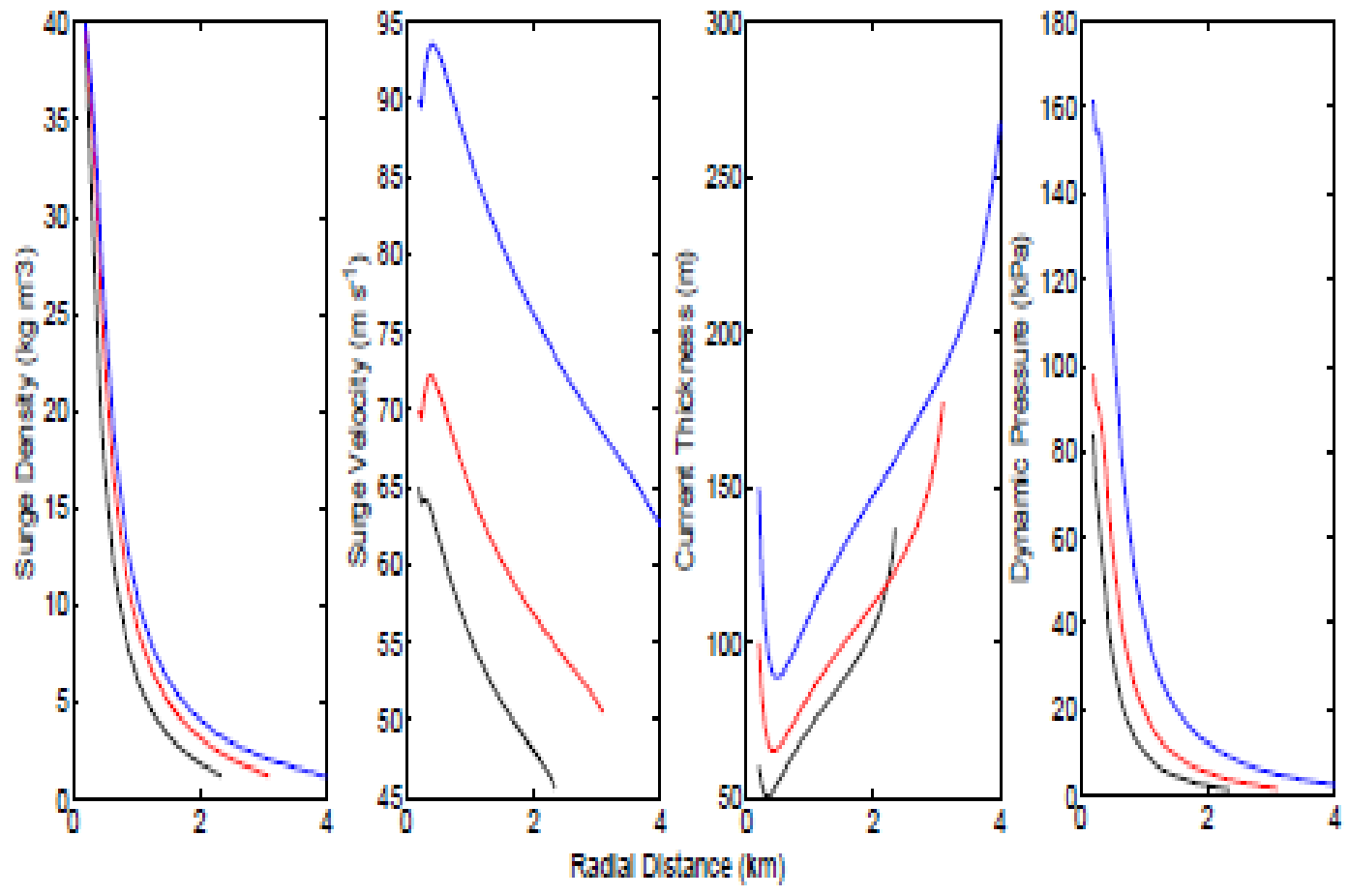

Figure 13 
NOTICE: this is the author's version of a work that was accepted for publication in Journal of Volcanology and Geothermal Research. Changes resulting from the publishing process, such as peer review, editing, corrections, structural formatting, and other quality control mechanisms may not be reflected in this document. Changes may have been made to this work since it was submitted for publication. A definitive version was subsequently published in Journal of Volcanology and Geothermal Research, (2014). DOI: 10.1016/j.jvolgeores.2014.01.008
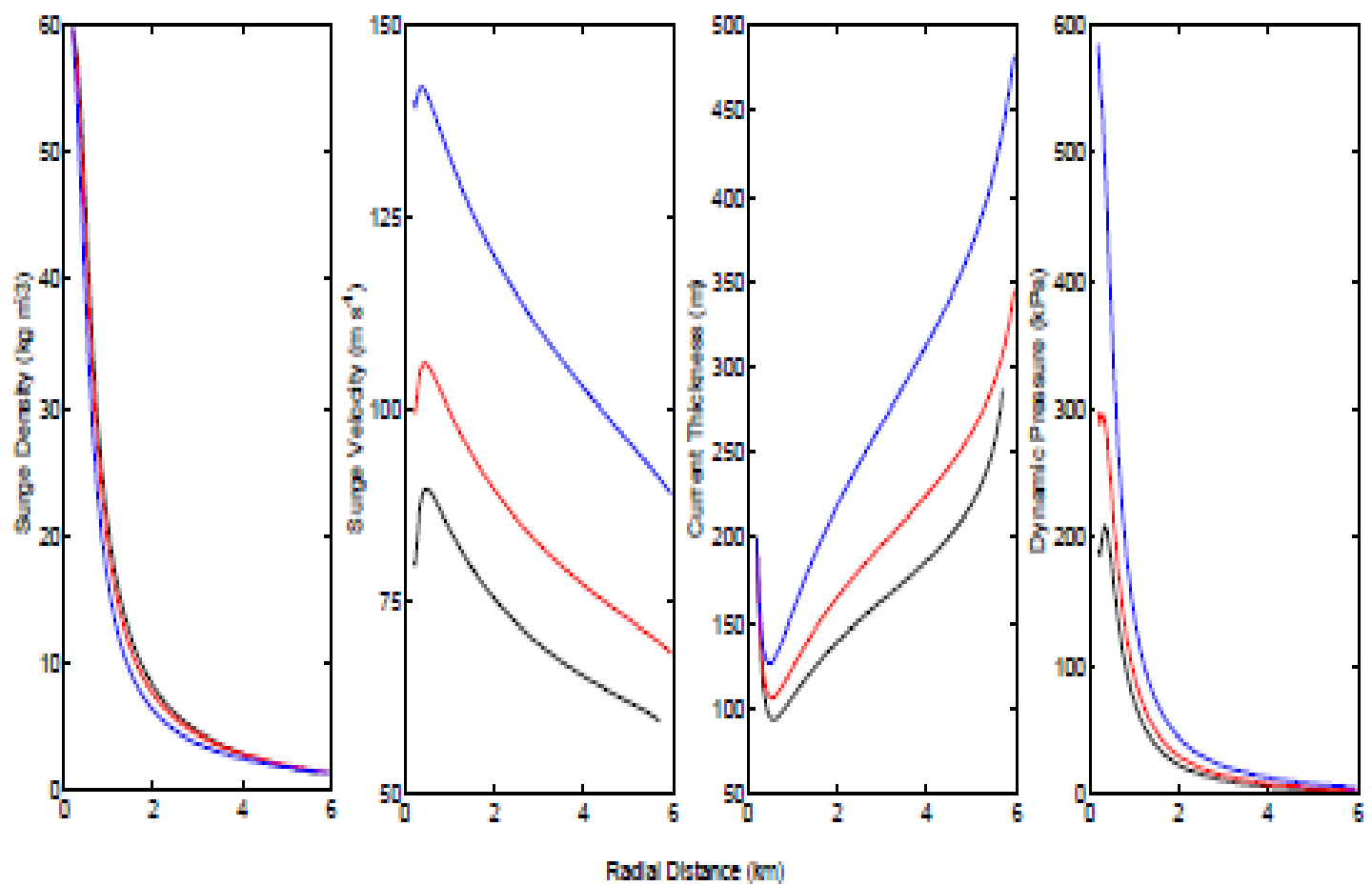

Figure 14 
NOTICE: this is the author's version of a work that was accepted for publication in Journal of Volcanology and Geothermal Research. Changes resulting from the publishing process, such as peer review, editing, corrections, structural formatting, and other quality control mechanisms may not be reflected in this document. Changes may have been made to this work since it was submitted for publication. A definitive version was subsequently published in Journal of Volcanology and Geothermal Research, (2014). DOI: 10.1016/j.jvolgeores.2014.01.008

\section{Research Highlights:}

- Field and numerical techniques are combined to understand pyroclastic currents (PDCs)

- PDCs produced by AVF eruptions could cause severe damage up to distances of $5 \mathrm{~km}$

- Bulk density and initial thickness have the greatest control on dilute PDC runout

- Increased velocity or slope result in rapid entrainment, shortening PDC runout

- This models can be used to predict base surge hazards in monogenetic fields 